\title{
Ambient black carbon particle hygroscopic properties controlled by mixing state and composition
}

\author{
D. Liu ${ }^{1}$, J. Allan ${ }^{1,4}$, J. Whitehead ${ }^{1}$, D. Young ${ }^{1}$, M. Flynn ${ }^{1}$, H. Coe ${ }^{1}$, G. McFiggans ${ }^{1}$, Z. L. Fleming ${ }^{2,5}$, and B. Bandy \\ ${ }^{1}$ Centre for Atmospheric Science, School of Earth, Atmospheric and Environmental Sciences, University of Manchester, \\ Manchester, M13 9PL, UK \\ ${ }^{2}$ Department of Chemistry, University of Leicester, Leicester, LE1 7RH, UK \\ ${ }^{3}$ School of Environmental Sciences, University of East Anglia, Norwich Research Park, Norwich, NR4 7TJ, UK \\ ${ }^{4}$ National Centre for Atmospheric Science, University of Manchester, Manchester, UK \\ ${ }^{5}$ National Centre for Atmospheric Science, University of Leicester, Leicester, UK \\ ${ }^{6}$ National Centre for Atmospheric Science, University of East Anglia, Norwich, UK
}

Correspondence to: D. Liu (dantong.liu@manchester.ac.uk)

Received: 30 October 2012 - Published in Atmos. Chem. Phys. Discuss.: 8 November 2012

Revised: 22 January 2013 - Accepted: 11 February 2013 - Published: 21 February 2013

\begin{abstract}
The wet removal of black carbon aerosol (BC) in the atmosphere is a crucial factor in determining its atmospheric lifetime and thereby the vertical and horizontal distributions, dispersion on local and regional scales, and the direct, semi-direct and indirect radiative forcing effects. The in-cloud scavenging and wet deposition rate of freshly emitted hydrophobic BC will be increased on acquisition of more-hydrophilic components by coagulation or coating processes. The lifetime of $\mathrm{BC}$ is still subject to considerable uncertainty for most of the model inputs, which is largely due to the insufficient constraints on the BC hydrophobicto-hydrophilic conversion process from observational field data. This study was conducted at a site along UK North Norfolk coastline, where the BC particles were transported from different regions within Western Europe. A hygroscopicity tandem differential mobility analyser (HTDMA) was coupled with a single particle soot photometer (SP2) to measure the hygroscopic properties of $\mathrm{BC}$ particles and associated mixing state in real time. In addition, a Soot Particle AMS (SP-AMS) measured the chemical compositions of additional material associated with $\mathrm{BC}$ particles. The ensemble of BC particles persistently contained a less-hygroscopic mode at a growth factor (gf) of around 1.05 at $90 \% \mathrm{RH}$ (dry diameter $163 \mathrm{~nm}$ ). Importantly, a more-hygroscopic mode of $\mathrm{BC}$ particles was observed throughout the experiment, the gf of these BC particles extended up to $\sim 1.4-1.6$ with the minimum between this and the less hygroscopic mode at a
\end{abstract}

gf $\sim 1.25$, or equivalent effective hygroscopicity parameter $\kappa$ $\sim 0.1$. The gf of $\mathrm{BC}$ particles $\left(\mathrm{gf}_{\mathrm{BC}}\right.$ ) was highly influenced by the composition of associated soluble material: increases of $\mathrm{gf}_{\mathrm{BC}}$ were associated with secondary inorganic components, and these increases were more pronounced when ammonium nitrate was in the $\mathrm{BC}$ particles; however the presence of secondary organic matter suppressed the $\mathrm{gf}_{\mathrm{BC}}$ below that of pure inorganics. The Zdanovskii-Stokes-Robinson (ZSR) mixing rule captures the hygroscopicity contributions from different compositions within $\pm 30 \%$ compared to the measured results, however is subject to uncertainty due to the complex morphology of BC component and potential artefacts associated with semivolatile particles measured with the HTDMA. This study provides detailed insights on BC hygroscopicity associated with its mixing state, and the results will importantly constrain the microphysical mixing schemes of BC as used by a variety of high level models. In particular, this provides direct evidence to highlight the need to consider ammonium nitrate ageing of $\mathrm{BC}$ particles because this will result in particles becoming hydrophilic on much shorter timescales than for sulphate formation, which is often the only mechanism considered. 


\section{Introduction}

Black carbon, or soot aerosols (BC) as a strong absorber of solar radiation, significantly perturb the radiative budget of the atmosphere, contribute to radiative forcing through heating the lower atmosphere (Ramanathan and Carmichael, 2008) and cause modifications to cloud cover through the semi-direct effect (Koch and Del Genio, 2010). In order to better predict their radiative effects, a key process to understand is their removal through wet deposition, which affects their atmospheric lifetime. This in turn influences their vertical and horizontal distributions and the overall timeintegrated radiative impacts. The main removal mechanism for the internally mixed BC is wet deposition through scavenging, where aerosol particles become incorporated into cloud droplets as cloud condensation nuclei $(\mathrm{CCN})$ or are directly scavenged via impaction onto cloud and rain droplets (Jacobson, 2012). Given their initial hydrophobic properties, for wet deposition to become favourable, BC particles need to acquire and be mixed with more hydrophilic components.

The mixing state of soot particles is initially determined at source. For example, diesel soot particles can be mixed with considerable amounts of unburned organic compounds and sulphate (e.g. Weingartner et al., 1997; Gysel et al., 2003; Petzold et al., 2005), the presence of the latter somewhat increasing its hygroscopicity (Gysel et al., 2003). Soot aerosols from biomass burning contain a significant fraction of organics and are initially more mixed compared to urban emissions (Schwarz et al., 2008). After emission, the soot particles can be further mixed with secondary species and chemically modified through different mechanisms during transport, i.e. through the condensation of semi-volatile vapours, heterogeneous interactions with gas-phase species or coagulation with pre-existing particles.

It has long been established that the freshly emitted or less mixed soot particles are of low hygroscopicity, and will not readily act as cloud condensation nuclei (CCN) (Lammel and Novakov, 1995; Weingartner et al., 1997; Dusek et al., 2006; Koehler et al., 2009; Snider et al., 2010). A variety of laboratory studies have been conducted to investigate how coatings or chemical reactions occurring on the soot particle could modify its initial low hygroscopicity to the point where eventually the soot particle could exhibit CCN activity. These experiments include investigations on soot from diesel engines (Weingartner et al., 1997; Gysel et al., 2003; Petzold et al., 2005; Tritscher et al., 2011), wood burning (Henning et al., 2010; Snider et al., 2010) and a variety of flame generators using different chemical fuels (Zuberi et al., 2005; Zhang et al., 2008; Koehler et al., 2009).

These laboratory studies attempted to simulate the different soot mixtures existing in the real atmosphere. One example are the comprehensive studies on flame generated soot coated with sulphuric acid vapour; which has been consistently found to considerably increase its hygroscopicity (i.e. Zhang et al., 2008; Khalizov et al., 2009 and references therein), and the sulphur coating has been found to be irreversible even under low pressure conditions (Zhang and Zhang 2005). The CCN activity of diesel engine emissions have been observed to be enhanced when coated with sulphuric acid, but this was partly suppressed if the coating contained significant fractions of non-volatile organic material (Petzold et al., 2005). Recent studies also include photochemically processed diesel soot coated with secondary organic aerosol (Tritscher et al., 2011), biomass burning soot simulated by coating spark generated soot with levoglucosan (Henning et al., 2010), soot mixed with sodium chloride (Dusek et al. 2006) and exposing soot to a highly oxidized environment with nitric acid, ozone or $\mathrm{OH}$ radials (i.e. $\mathrm{Zu}$ beri et al., 2005; Aubin and Abbatt, 2007).

A general consensus has been reached in these studies that the initial low hygroscopicity of soot particles can be modified through a wide variety of different mechanisms. These experimentally treated soot particles activate at relatively low supersaturations when mixed with more hygroscopic components or are subjected to heterogeneous chemical reactions. The extended classic Köhler theory has been applied for most of the studies to include the insolubility of BC inclusion (i.e. Weingatner et al., 1997; Zhang et al., 2008; Henning et al., 2010), which has mostly explained the increased hygroscopicity of soot particles by attributing the hygroscopicity from each of the components present.

To date, direct measurements of BC hygroscopic properties in the atmosphere are very sparse. One of the previously used techniques was to couple hygroscopic measurements with the volatility tandem differential mobility analyzer (VTDMA) system, in which the VTDMA was used to isolate the less volatile aerosol components, which were considered to be mainly composed of $\mathrm{BC}$ at close proximity to urban environments (Kuwata et al., 2007; Rose et al., 2011). The recent deployment of the single particle soot photometer (SP2) allows the quantitative determination of $\mathrm{BC}$ coating content with high time resolution. McMeeking et al. (2011) coupled the hygroscopicity tandem differential mobility analyser (HTDMA) with the SP2 to directly monitor the hygroscopic growth of BC particles in real time. Both the VTDMA and SP2 can examine the mixing state of BC, i.e. the amount of non- $\mathrm{BC}$ material in a particle, but are not able to provide the chemical compositions of these materials. The variability in chemical compositions adds complexities when determining how the mixing state will influence the $\mathrm{BC}$ hygroscopic properties.

This paper presents a study of the hygroscopic properties of atmospheric BC particles that have undergone a degree of processing since emission, typical of polluted, mid-latitude, continental environments. This data will provide valuable constraints when testing model treatments designed to simulate the effects on particle properties. 

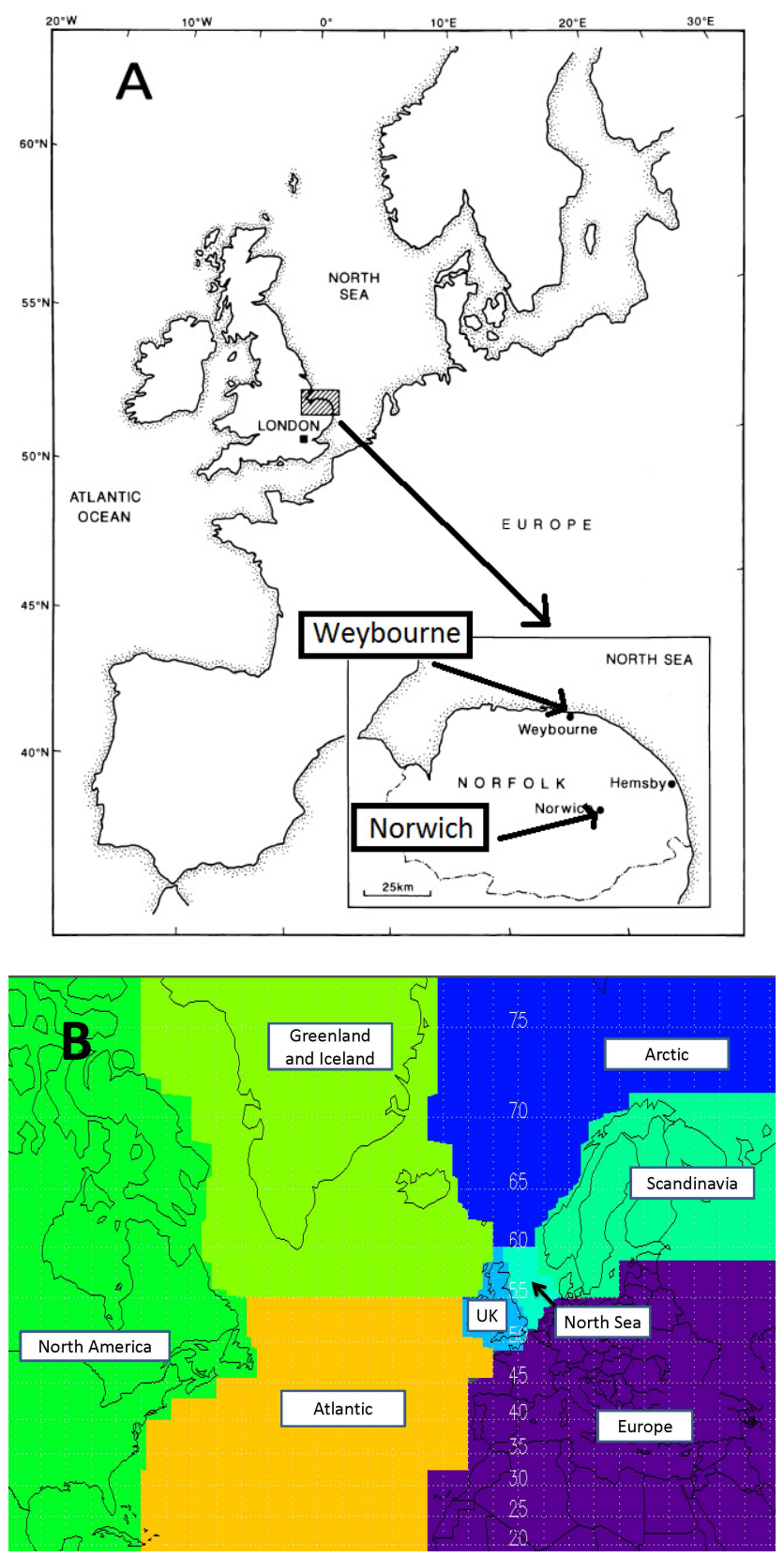

Fig. 1. (a) The location of Weybourne Atmospheric Observatory; (b) the categories of air masses according to the regions within the domain of passage for 3 day footprints in the NAME model.

\section{Experimental site, instrumentations and data analysis}

This study was conducted at the Weybourne Atmospheric Observatory (WAO) $\left(52.9504^{\circ} \mathrm{N}, 1.1219^{\circ} \mathrm{E}\right)$ from JuneJuly, 2011 as part of the NERC project "Multiscale Chemical Composition of Carbonaceous particles and Coatings (MC4)". The WAO is located near the North Norfolk coastline (as shown in Fig. 1a) and represents a rural environment remote from major populated or industrial areas (Pen- kett et al., 2007). This site routinely experiences polluted plumes from the UK and mainland Europe and has been used during previous campaigns such as TORCH 2 (Gysel et al., 2007). In order to identify the origin of plumes experienced and estimate transit times, the UK Met Office Numerical Atmospheric-dispersion Modelling Environment (NAME) was run using Unified Model (UM) meteorological data to generate hourly surface source footprints that describe the origin and pathways of air arriving at the site after 1,2 or 3 days' transport. The air masses were categorized according to the main regions within the domain of passage (i.e. over the UK mainland, continental Europe, the North Sea or long transport from Atlantic, North America and the Arctic) for the 3 day footprints (Fig. 1b) according to the technique described in Fleming et al. (2012) and the contributions from each category of air mass were then calculated as fractions for each hour. The air arriving at this coastal site can have a variety of influences and this method highlights the periods that are influenced by combined types of air masses. The time periods where the air mass fraction was greater than the 40th percentile of that region's average air mass fraction were deemed to be dominant with that specified air mass type, as shown in the top panel of Fig. 3.

The concentrations of trace gases including carbon monoxide $(\mathrm{CO})$, nitrogen oxides $\left(\mathrm{NO}_{\mathrm{x}}\right)$ and ozone $\left(\mathrm{O}_{3}\right)$ were continuously measured at WAO as part of the National Centre for Atmospheric Science (NCAS) Facilities for Groundbased Atmospheric Measurement (FGAM). The Ozone instrument is a Thermo Electron 49c that is run as part of the DEFRA sponsored national network AURN (Automatic urban and Rural Network), whilst the carbon monoxide instrument used was an Aero-laser AL 5002 VUV Fast Fluorescence $\mathrm{CO}$ Analyser. The data of $\mathrm{NO}_{\mathrm{x}}$ in June. was derived from an Annox instrument (CRANOX models CLD770 and PLC 760) and in July. a Thermo 42c analyser was used. The time resolved ambient chemical mass loadings and distributions of key submicron non-refractory components of the aerosol, such as nitrate, sulphate and organic matter, were measured by an Aerodyne compact Time of Flight Aerosol Mass Spectrometer (cToF-AMS) (Canagaratna et al., 2007). The key instruments closely related to this study are described in detail in 2.1 and 2.2.

\subsection{HTDMA-SP2 system}

The physical properties of individual refractory $\mathrm{BC}$ particles (rBC) were characterized by the single particle soot photometer (SP2) (Baumgardner et al., 2004; Schwarz et al., 2006). The instrument operation and data interpretation procedures of Manchester SP2 instrument have been described elsewhere (Liu et al., 2010; McMeeking et al., 2010). Briefly, the SP2 uses an intra-cavity Nd:YAG laser at $1064 \mathrm{~nm}$ to determine the optical size of a single particle by light scattering and if material within the particle absorbs at the laser wavelength, the refractory mass of the particle will be quantified 


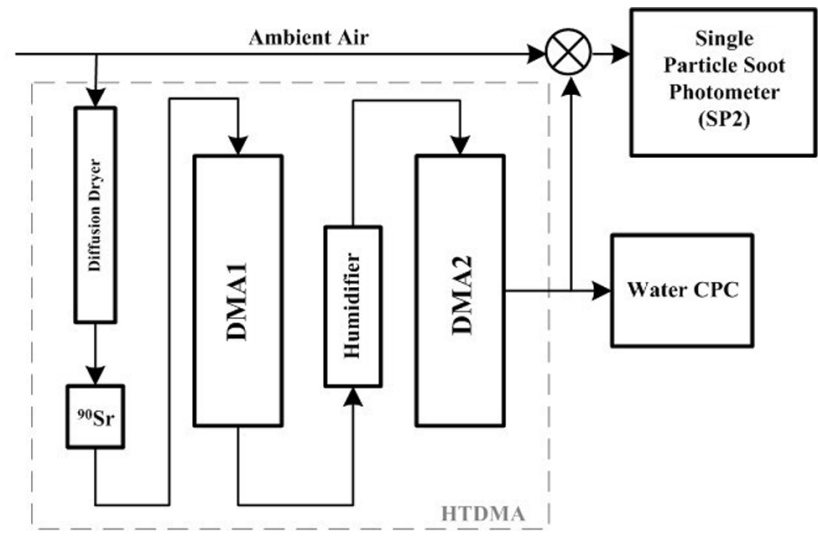

Fig. 2. The schematic of HTDMA-SP2 set up.

by detection of the laser induced incandescence radiation. In the atmosphere the main light-absorbing component in particulate is BC. The SP2 incandescence signal was used to obtain single particle $\mathrm{rBC}$ mass after calibration using the Aquadag samples standard (Aqueous Deocculated Acheson Graphite, manufactured by Acheson Inc., USA). The Aquadag was size selected using a differential mobility analyzer (DMA), and the particle mass at each mobility diameter $\left(D_{\mathrm{mob}}\right)$ was obtained by assigning an effective density from Gysel et al. (2011). The Aquadag mass in single particle was calibrated at $\sim 0.5-80 \mathrm{fg}\left(D_{\mathrm{mob}} \sim 80-600 \mathrm{~nm}\right)$, and the calibration curve is further recalculated to be compliant with the physical properties of ambient BC particles by applying a scaling factor of 0.75 according to Baumgardner et al. (2012) and Laborde et al. (2012). The SP2 measurement is capable of examining whether a single particle contains $\mathrm{rBC}$ or not by detecting the ambient incandescence signal. In this study, any absorbing single particle with a detectable SP2 incandescence signal is termed a "BC-containing particle" or referred to as a $\mathrm{BC}$ particle in the following discussions, whereas a particle which only exhibits a scattering signal and the incandescence signal is below the SP2 triggering threshold is termed a "BC-free particle". In this study, the SP2 sample line was switched between direct ambient measurements and at the downstream of a HTDMA as illustrated below.

The hygroscopicity of aerosols is frequently investigated using the hygroscopicity tandem differential mobility analyser (HTDMA, Cubison et al., 2005; Duplissy et al., 2009). In brief, the particles were dried to $\mathrm{RH} \sim 20 \%$ and sizeselected using the first DMA (dry DMA). The monodisperse particles at a given mobility size were then exposed to a high RH $(\sim 90 \%)$ to allow water uptake on particles. The mobility sizes of humidified particles were scanned by a second DMA (wet DMA) and the number concentrations at each scanned size are measured using a condensation particle counter (water-CPC, TSI 3782). At a given dry size $\left(D_{\mathrm{p}}\right)$ and sub-saturation condition, the of of a particle is derived from the ratio between the size of humidified particle $\left(D_{\mathrm{w}}\right)$ and the particle dry size $\left(\mathrm{gf}=D_{\mathrm{w}} / D_{\mathrm{p}}\right)$. The HTDMA-SP2 system (Fig. 2 shows the instrumental configuration) couples the SP2 measurement downstream of the wet DMA (McMeeking et al., 2011), allowing the water-CPC and the SP2 to detect the humidified particles simultaneously. Given that the SP2 can discriminate BC-containing and BC-free particles, at each gf scan of the humidified particles, the number of $\mathrm{BC}$ containing and $\mathrm{BC}$-free particles can be determined. Multiply charged particles were rejected from data analysis using the SP2's sizing capability based on scattering signals. The inversion methodology introduced by Gysel et al. (2009) was applied to both CPC and SP2 counts. The particles were selected at dry sizes of $163 \mathrm{~nm}$ and $259 \mathrm{~nm}$ during the experiment to ensure that BC-free particles would large enough to be reliably detected, however as the particle counts at higher sizes were low, the inversion could not be robustly applied at the $259 \mathrm{~nm}$ size and this study will only report the results of particles at $163 \mathrm{~nm}$.

One of the main uncertainties associated with the HTDMA-measured gf of soot particles is the effect of soot morphology on its mobility diameter. For a non-spherical particle, such as a fresh soot agglomerate, the mobility diameter $\left(D_{\text {mob }}\right)$ as measured by a DMA is normally larger than the geometric volume/mass equivalent diameter $\left(D_{\mathrm{ve}}\right)$ (DeCarlo et al., 2004). However, it has been widely reported that the coating on soot aggregates will modify its morphology (Weingartner et al., 1997; Zhang et al., 2008; Lewis et al., 2009; Pagels et al., 2009; Kiselev et al., 2010) by causing the soot aggregate to collapse and to become less fractal and more compact. The modification of the particle morphology will change its physical mobility properties, and therefore measurements of $D_{\text {mob }}$. It has been observed that more compacted, reconstructed soot particles will exhibit decreased mobility diameter and increased effective density (i.e. Zhang et al., 2008; Pagels et al., 2009). In HTDMA measurements, if the BC-containing particle shape is significantly fractal, the dry DMA will have a relatively large $D_{\text {mob }}$, however after experiencing some reconstruction process in the HTDMA (i.e. the water adsorption in HTDMA pre-humidifier), the particle will become more compact and show a decreased $D_{\text {mob }}$ as scanned by wet DMA, therefore gf for fractal soot particles will be underestimated. These effects are less pronounced for more internally-mixed particles since they will be less fractal before sizing in the instrument.

\subsection{SP-AMS}

The Soot Particle Aerosol Mass Spectrometer (SP-AMS) was used as introduced by Onasch et al. (2012). Briefly, the instrument is a standard AMS (Canagaratna et al., 2007) that has had its vaporiser removed and replaced with a Nd:YAG laser similar to that used in the SP2. This means that particles are vaporised inside the active cavity of the laser rather than on contact with a heated surface. In the same manner as the SP2, only particles that contain laser light absorb 
Table 1. Average values of properties of ambient aerosols, BC-containing particles and hygroscopicity of BC-containing particles. The data in each table cell represents the mean \pm standard deviation, median.

\begin{tabular}{|c|c|c|c|c|c|}
\hline $\begin{array}{l}\text { Air Mass } \\
\text { Classifications }\end{array}$ & UK & Europe & NorthSea & Atlantic & Arctic \\
\hline \multicolumn{6}{|c|}{ Properties of ambient aerosols and gases } \\
\hline $\mathrm{rBC}\left(\mu \mathrm{g} \mathrm{m}^{-3}\right)$ & $0.17 \pm 0.08,0.15$ & $0.17 \pm 0.10,0.14$ & $0.14 \pm 0.09,0.12$ & $0.12 \pm 0.06,0.11$ & $0.12 \pm 0.07,0.11$ \\
\hline Organic $\left(\mu \mathrm{g} \mathrm{m}^{-3}\right)$ & $1.71 \pm 1.09,1.50$ & $1.83 \pm 1.57,1.25$ & $1.70 \pm 1.17,1.50$ & $0.91 \pm 0.59,0.76$ & $1.00 \pm 0.48,0.95$ \\
\hline Nitrate $\left(\mu \mathrm{g} \mathrm{m}^{-3}\right)$ & $1.02 \pm 1.46,0.51$ & $1.15 \pm 1.66,0.47$ & $1.16 \pm 1.80,0.36$ & $0.44 \pm 0.91,0.18$ & $0.52 \pm 0.89,0.24$ \\
\hline Sulphate $\left(\mu \mathrm{g} \mathrm{m}^{-3}\right)$ & $1.06 \pm 0.58,0.96$ & $1.09 \pm 0.66,0.95$ & $1.31 \pm 0.73,1.16$ & $0.71 \pm 0.42,0.58$ & $0.81 \pm 0.47,0.71$ \\
\hline $\mathrm{CO}$ (ppbv) & $167.8 \pm 25.3,165.3$ & $156.4 \pm 30.7,150.7$ & $159.2 \pm 23.1,159.2$ & $153.6 \pm 22.1,150.5$ & $163.1 \pm 17.5,159.5$ \\
\hline $\mathrm{O}_{3}$ (ppbv) & $35.67 \pm 9.34,35.20$ & $35.59 \pm 11.37,34.40$ & $38.91 \pm 9.79,38.90$ & $30.82 \pm 8.27,31.65$ & $35.44 \pm 8.41,35.15$ \\
\hline NO (ppbv) & $0.57 \pm 0.94,0.19$ & $0.55 \pm 0.87,0.26$ & $0.50 \pm 0.86,0.20$ & $0.47 \pm 0.53,0.29$ & $0.53 \pm 0.68,0.28$ \\
\hline $\mathrm{NO}_{2}$ (ppbv) & $1.51 \pm 1.16,1.18$ & $2.06 \pm 1.82,1.42$ & $1.65 \pm 1.60,1.07$ & $1.43 \pm 1.37,0.87$ & $1.03 \pm 0.78,0.83$ \\
\hline \multicolumn{6}{|c|}{ Coating properties for BC-containing particles $(\varepsilon$, volume fraction $\%)$ at $D_{\mathrm{mob}}=163 \mathrm{~nm}$} \\
\hline $\mathrm{rBC}$ fraction & $58.8 \pm 16.1,59.1$ & $58.9 \pm 17.4,59.8$ & $57.8 \pm 15.8,58.1$ & $59.5 \pm 17.9,60.8$ & $57.7 \pm 16.9,59.3$ \\
\hline Organic coating & $25.6 \pm 13.4,23.5$ & $26.2 \pm 14.1,22.7$ & $26.4 \pm 12.5,25.0$ & $28.2 \pm 14.7,25.3$ & $27.1 \pm 14.0,26.4$ \\
\hline Nitrate coating & $8.8 \pm 7.4,6.4$ & $8.5 \pm 7.1,6.9$ & $7.5 \pm 7.0,5.2$ & $6.2 \pm 5.6,4.2$ & $6.6 \pm 5.2,5.1$ \\
\hline Sulphate coating & $6.8 \pm 4.9,5.7$ & $6.4 \pm 4.7,5.1$ & $8.3 \pm 6.4,6.5$ & $6.1 \pm 4.0,4.9$ & $7.8 \pm 6.0,5.9$ \\
\hline \multicolumn{6}{|c|}{ Hygroscopic Properties of BC-containing particles at $D_{\mathrm{mob}}=163 \mathrm{~nm}$} \\
\hline Averaged gf & $1.24 \pm 0.09,1.23$ & $1.24 \pm 0.09,1.23$ & $1.25 \pm 0.10,1.25$ & $1.20 \pm 0.08,1.18$ & $1.21 \pm 0.09,1.19$ \\
\hline Averaged $\kappa$ & $0.10 \pm 0.05,0.10$ & $0.10 \pm 0.05,0.09$ & $0.11 \pm 0.05,0.11$ & $0.08 \pm 0.04,0.07$ & $0.09 \pm 0.04,0.08$ \\
\hline $\begin{array}{l}\text { Hygroscopic } \\
\text { fraction }\left(F_{\text {hygro }}\right)\end{array}$ & $0.33 \pm 0.22,0.32$ & $0.32 \pm 0.22,0.30$ & $0.38 \pm 0.23,0.38$ & $0.23 \pm 0.20,0.19$ & $0.24 \pm 0.20,0.22$ \\
\hline
\end{tabular}

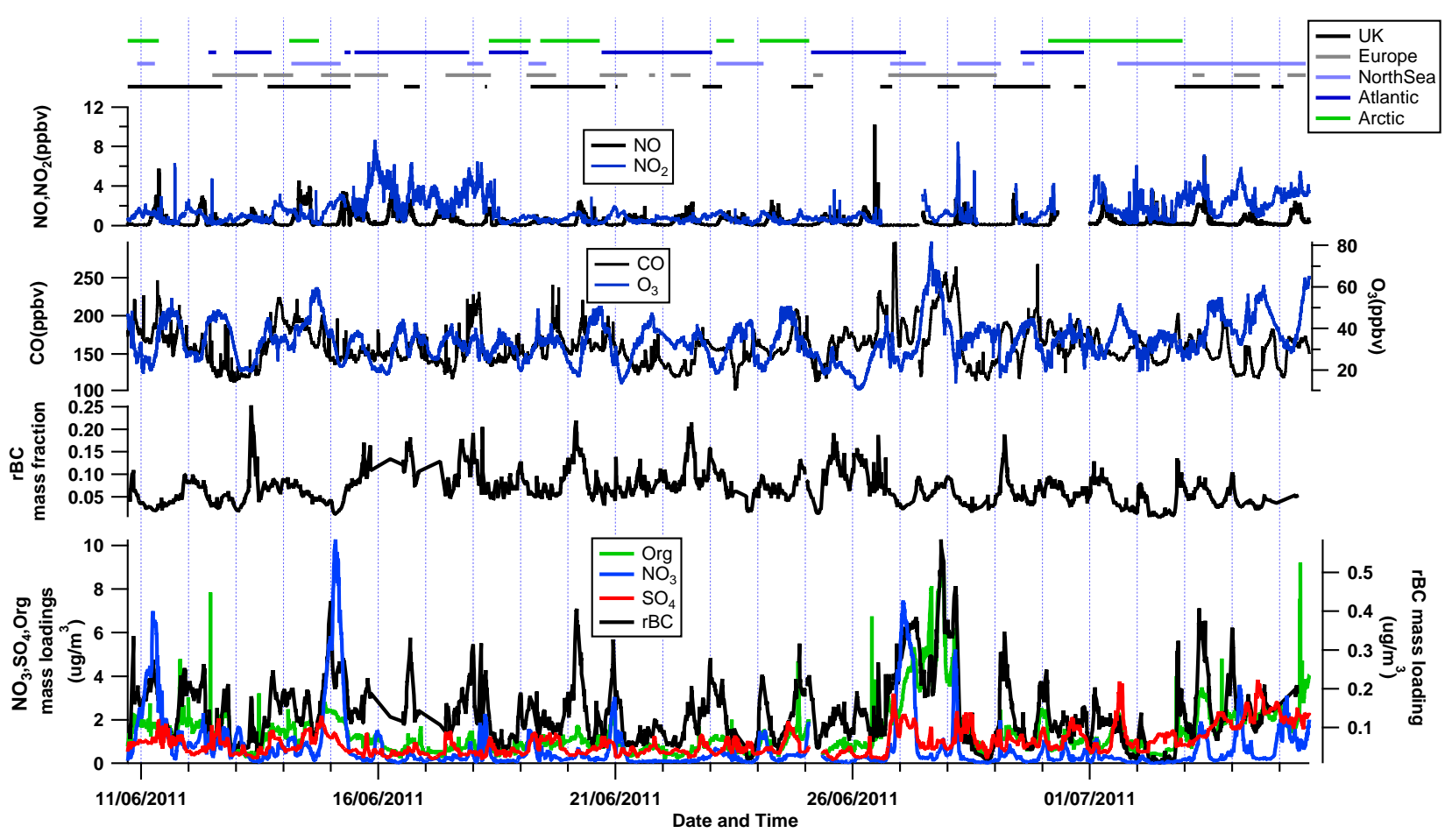

Fig. 3. An overview of aerosol masses, trace gas concentrations measured at WAO during the experiment. The classifications of air mass history are according the regional air mass contributions obtained from the 3-day NAME dispersion model footprints (Fleming et al., 2012). 


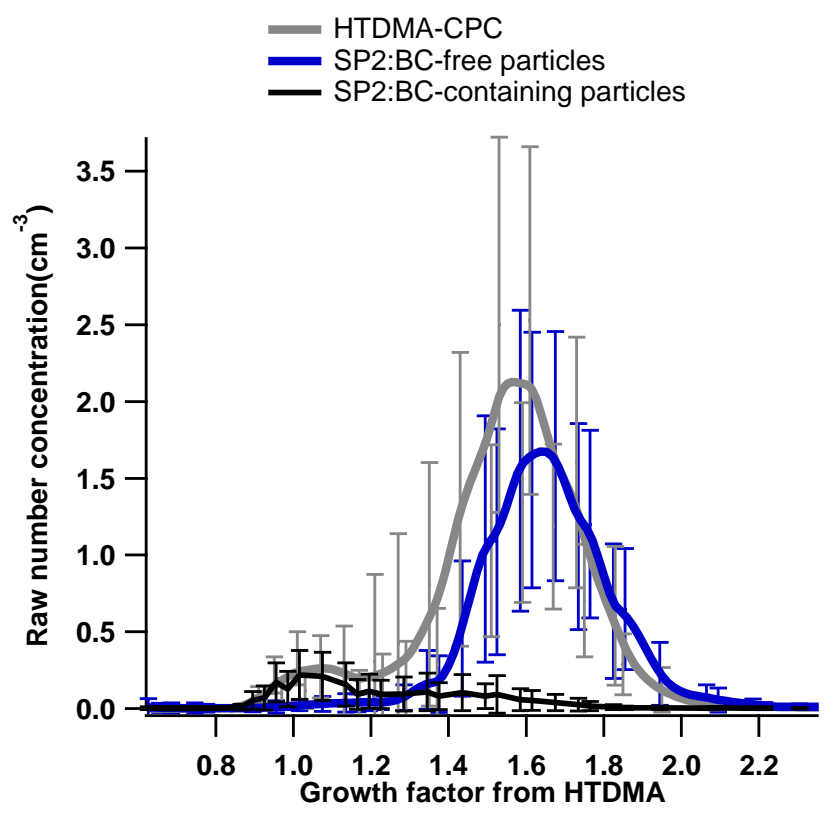

Fig. 4. Comparison between the raw HTDMA-CPC counts (before the HTDMA inversion is applied) and HTDMA-SP2 counts as a function of gf at $D_{\mathrm{mob}}=163 \mathrm{~nm}$ and $\mathrm{RH}=90 \%$. Error bars denote \pm one standard deviation $(\sigma)$ during the entire experiment.

the $1064 \mathrm{~nm}$ light, so these are selectively vaporised. This way, the mass concentrations reported by the SP-AMS are restricted to those that contain $\mathrm{BC}$. As such, these data are more likely to be representative of the $\mathrm{BC}$ coatings than the data from a standard AMS.

The mass spectra reported by the instrument were largely similar in nature to those reported by a normal AMS, with the addition of elemental carbon peaks at $m / z 24,36$ and 48 . While the peaks seen were very similar to normal AMS data, the relative sizes of the peaks were different, showing a bias towards larger masses. In particular, the sulphate peaks are biased towards $m / z 81\left(\mathrm{HSO}^{3+}\right)$, which was also seen by Onasch et al. (2012). This is due to the lower effective temperature of vaporisation. The mass concentrations were calculated from the unit mass resolution (UMR) $\mathrm{V}$ mode data using the fragmentation table technique (Allan et al., 2004). While there was some interference at the $m / z 48$ peak between $\mathrm{C}^{4+}$ and $\mathrm{SO}^{+}$ions, high resolution analysis (DeCarlo et al., 2006) showed the majority was due to $\mathrm{SO}^{+}$ions.

For the purposes of this work, it is only necessary to quantify the relative concentrations of the different species present in the coatings, so absolute quantification is not needed. A more detailed analysis will be presented in Young et al. (2013). Like the standard AMS, the SP-AMS quantifies particulate matter in bulk, as opposed to analysing individual particles like the SP2.

\section{Results and discussions}

\subsection{Overview of measurements}

An overview of aerosol masses, trace gas concentrations measured at WAO during the experiment is shown in Fig. 3. The $\mathrm{rBC}$ mass fraction in total sub-micron aerosol mass is calculated as the rBC mass divided by the sum of ammonium, nitrate, sulphate, organic and chloride mass measured by the cToF-AMS. The statistics of aerosol/gas concentrations for each category of air mass are summarized in Table 1. The averaged values in Table 1 are calculated for all periods with a strong influence from each region and periods with an overlap of regions will have been included in the averages of all those corresponding air mass types. The air masses from north Atlantic and Artic are relatively clean, as reflected by lower aerosol mass loadings of all species and lower $\mathrm{NO}_{\mathrm{x}}$ concentrations. The nitrate aerosol loading is significantly higher for the European air mass, which corresponds with a higher $\mathrm{NO}_{\mathrm{x}}$ concentration from that region (Table 1). This is consistent with the view that air from continental Europe contains a significant fraction of nitrate mass (Morgan et al., 2009). The air masses that pass over the UK are generally polluted, where the pollutants appear to be higher in the southern air masses, influenced by the London metropolitan area pollution (Young et al., 2013). Higher loadings of nitrate and sulphate were also observed for the North Sea air masses, which are often coupled with significant continental UK or Europe land contact. The mean nitrate loading is significantly higher than the median value for all air mass categories, indicating elevated nitrate loadings were largely event driven, a finding also observed by a UK aircraft synthesis study (Morgan et al., 2009). Nitrate events during this study were mostly linked to elevated BC particles, although during some periods $\mathrm{BC}$ elevations were associated with high loadings of organic or sulphate. Therefore the BC-containing particles measured at this site could have potentially been internally mixed with a variety of different components. The overall aerosol physiochemical properties related to atmospheric evolution and air masses at this site are described in detail by Young et al. (2013), whereas the properties of $\mathrm{BC}$-containing particles are the main focus of this study.

\section{2 gf of BC-containing particles and BC-free particles}

For each gf scan by the HTDMA, the CPC counts all of the particles whereas the SP2 is able to discriminate the counts of BC-containing and BC-free particles. The comparison between the raw CPC counts and the total SP2 counts (the sum of BC-containing and BC-free particles) downstream of the HTDMA shows good agreement (Fig. 4). The total SP2 counts and CPC counts agree within $\sim 8 \%$ for the entire experiment. It can be clearly seen that the $\mathrm{BC}$-free particles dominate the more hygroscopic mode with larger gf, whereas the $\mathrm{BC}$-containing particles dominate the particle numbers 


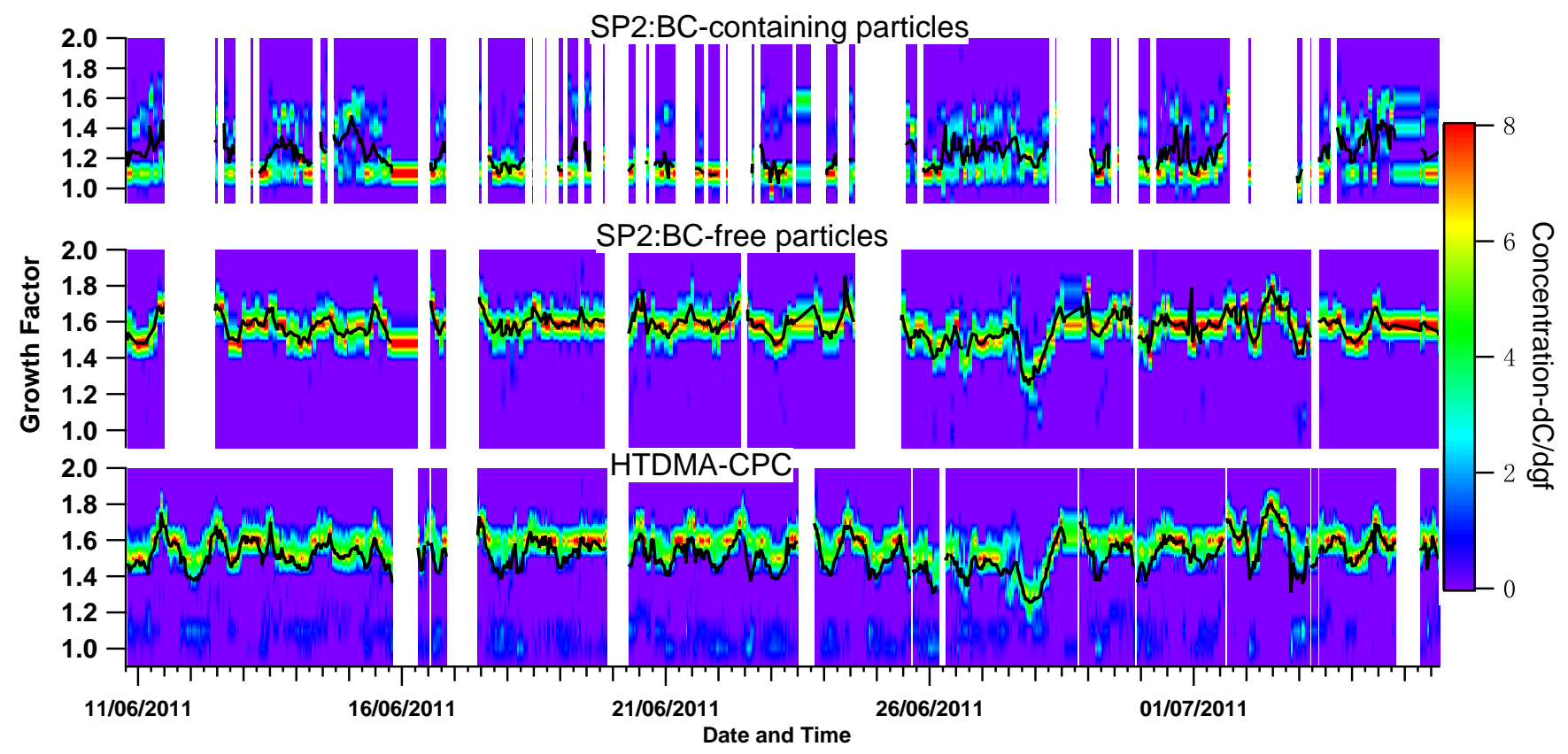

Fig. 5. The inverted gf distribution at $D_{\text {mob }}=163 \mathrm{~nm}$ for HTDMA CPC, HTDMA-SP2 measured BC-containing and BC-free particles. The black lines in each panel show the averaged gf for each complete HTDMA scan.
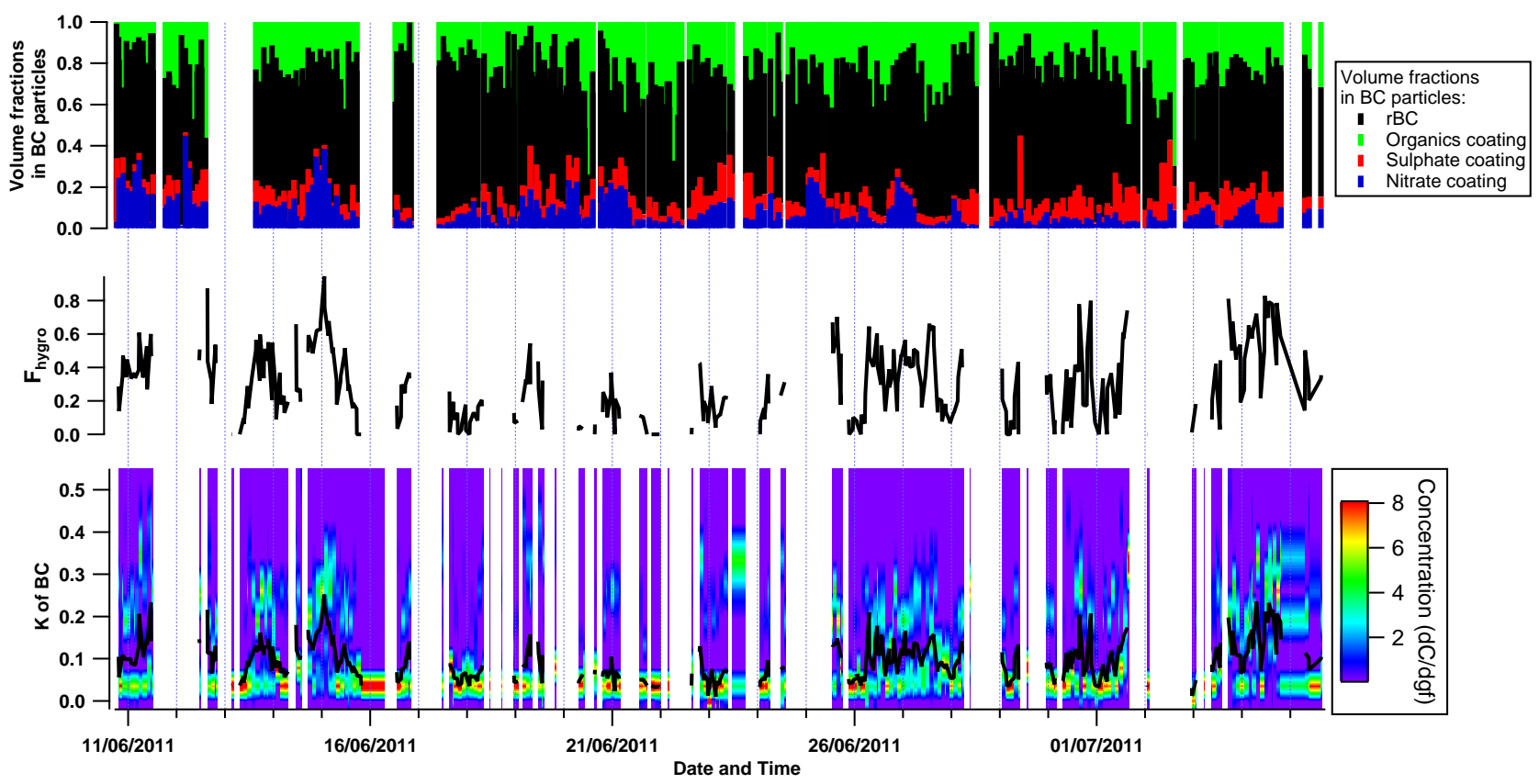

Fig. 6. Bottom panel: time series of the effective hygroscopicity parameter $(\kappa)$ distribution for BC-containing particles, the $\kappa$ is calculated from inverted gf measured by the HTDMA-SP2; the black line shows the time series of the average $\kappa$ from each scan. Middle panel: the number fraction of more-hygroscopic BC-containing particles. Top panel: the volume fractions in BC-containing particles contributed by different components (averaged over all BC-containing particles for each full HTDMA scan): refractory BC (rBC), organic matter coating, nitrate coating and sulphate coating. 


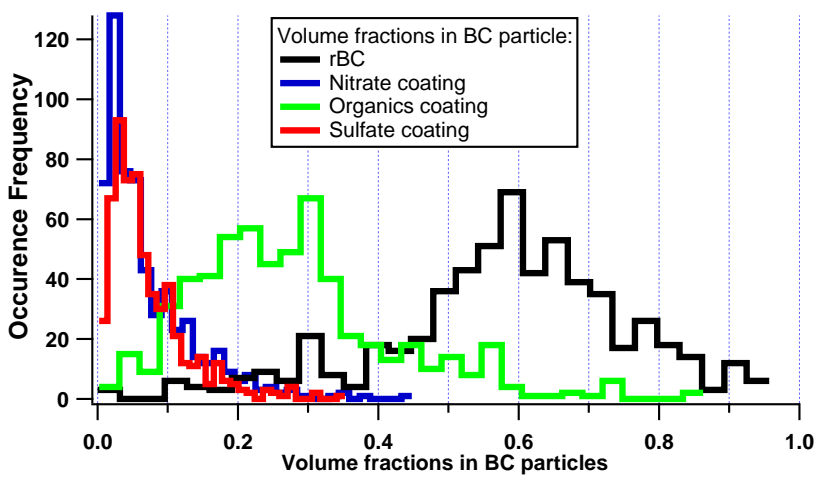

Fig. 7. Occurrence frequencies for the volume fractions of chemical compositions in BC-containing particles.

in the lower gf. However, some fraction of BC-containing particles exhibits some hygroscopicity with gf extending to the gf larger mode. A further investigation of the $\mathrm{rBC}$ cores (the refractory $\mathrm{BC}$ composition in a $\mathrm{BC}$-containing particle) shows that for a given dry size ( $D_{0}=163 \mathrm{~nm}$ in this study) of $\mathrm{BC}$-containing particles, the $\mathrm{rBC}$ core size decreases with increased gf, indicating the more hygroscopic $\mathrm{BC}$ has a fractionally lower $\mathrm{BC}$ content in favour of internally mixed soluble material.

The gf distributions after applying the HTDMA inversion method are shown in Fig. 5. The overall gf distributions of particles at $D_{\text {mob }}=163 \mathrm{~nm}$ exhibit apparent bimodality, and the HTDMA-CPC and HTDMA-SP2 are in good agreement. The more hygroscopic particles with gf $\sim 1.4-1.8$ mostly correspond to the $\mathrm{BC}$-free particles as measured by the HTDMA-SP2, and the less hygroscopic particles dominate with BC-containing particles. The BC-free particles contain nitrate, sulphate and organic matter according to the measurements of non-refractory compositions by AMS. The gf of BC-free particles are $>1.4$ throughout the experiment, apart from a pollution event on 28 June midnight, when a high loading of organic were observed (Fig. 3) and the gf significantly dropped down to $\sim 1.2$.

Consistent with the previous laboratory and field studies, the BC-containing particles persistently contain a lesshygroscopic mode at a $\mathrm{gf} \sim 1.05$. This gf is slightly higher than the gf $\sim 1$ for the less-hygroscopic mode of BCcontaining particles measured in an urban environment in the UK (McMeeking et al., 2011). This is not surprising as the experimental site in this study is away from urban sources, and the measured $\mathrm{BC}$ particles will likely have undergone some degree of atmospheric processing. Moreover, the measured gf of BC particles at the rural site is likely to be less affected by complex soot morphologies, because the soot agglomerates will become more compact after some atmospheric processing, whereas the measured gf of soot particles from fresh urban emissions is more likely to be underestimated due to its high fractal shape, as discussed in Sect. 2.1.
A more-hygroscopic mode of BC-containing particles was observed throughout the experiment. The gf of these BC particles can extend up to $\sim 1.4-1.6$, leading to a bimodal distribution in the growth factor spectrum. A minimum of $\mathrm{gf}$ $\sim 1.25$ on the average gf spectra of BC-containing particles was found to be representative of the experiment. It is noted that even the gf of more-hygroscopic BC-containing particles is generally lower than the gf of BC-free particles (gf 1.451.75 ) because the $\mathrm{BC}$ component has much lower hygroscopicity and the $\mathrm{BC}$ inclusion in these $\mathrm{BC}$-containing particles will occupy a volume that would otherwise contain soluble material, therefore suppressing their hygroscopicity relative to BC-free particles of the same dry size. The diurnal analysis of the hygroscopic properties of BC particles has not shown apparent day/night differences within the statistics of the datasets for the entire experimental period.

\subsection{The hygroscopicity of BC-containing particles associated with chemical compositions}

The effective hygroscopicity parameter $\kappa$ of BC-containing particles is derived from the inverted gf measured by the HTDMA-SP2, using Eq. (11) in Petters and Kreidenweis (2007). Corresponding with the bimodal distribution of gf with an average minimum at gf $\sim 1.25$ (Sect. 3.2), the $\kappa$ exhibits a bimodal distribution with a minimum $\kappa \sim 0.1$. A more hygroscopic mode of BC-containing particles is generally associated with $\mathrm{gf}>1.25$ or $\kappa>0.1$. The $\kappa$ derived from the measured gf will be also subject to instrument uncertainties as discussed in Sect. 2.1, i.e. the mobility sizing uncertainties due to soot morphology, the evaporation losses of semivolatile materials in HTDMA instrument (Gysel et al., 2007) or some soluble compounds may not have contributed the measured $\kappa$ (Petters and Kreidenweis, 2007).

By assuming internal/external mixing scenarios, Wang et al. (2010) found a threshold of $\kappa \sim 0.1$ in urban site of Mexico City, above which the aerosols including the BC particles could be treated as being internally-mixed and the CCN number concentration can be predicted within $20 \%$ at SS $\sim 0.11 \%-0.35 \%$. The threshold $\kappa \sim 0.1$ is consistent with the view here that the BC-containing particles with $\kappa>0.1$ may be considered to be "internally mixed" with respect of hygroscopicity, and could be treated identically with the other participating aerosol species. The number fraction of BC-containing particles with gf $>1.25$ or $\kappa>0.1$ ( $\left.F_{\text {hygro }}\right)$ are thus considered to be more hygroscopic at sub-saturation and more likely to be activated as $\mathrm{CCN}$ at supersaturation conditions. As Fig. 6 shows, the $F_{\text {hygro }}$ ranges between $0.1-$ 0.7 and varies with the coating compositions. The hygroscopicity parameters of $\mathrm{BC}$ as influenced by different air masses are summarized in Table 1.

In the real atmosphere, the exact $\kappa$ above which a given size of $\mathrm{BC}$ particle will be $\mathrm{CCN}$ activated will depend on the supersaturation conditions for different cloud types (McFiggans et al., 2006). Within instrument uncertainties, the 

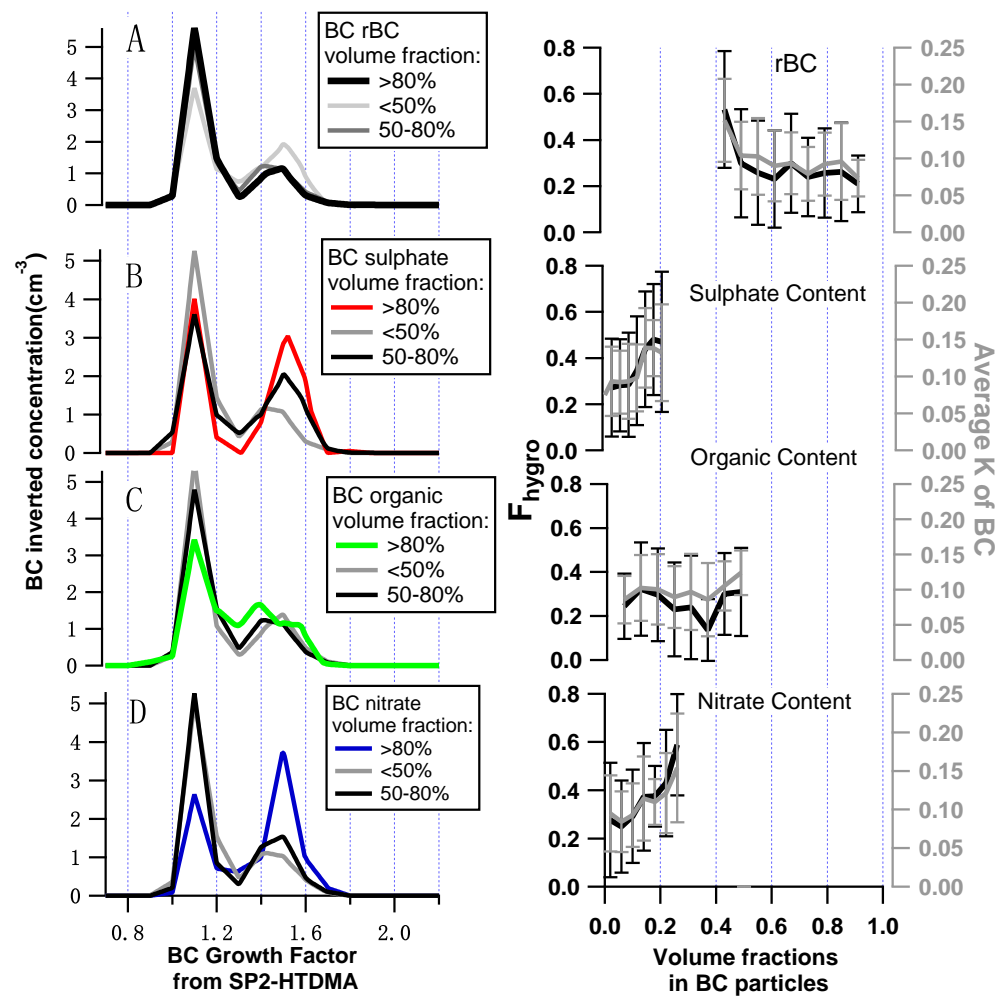

Fig. 8. Trends for entire experiment: left panel shows the gf distributions of BC-containing particles when the volume fractions of each component (rBC, organic, nitrate and sulphate) were $>50 \%$ percentile, $50 \%$ percentile- $80 \%$ percentile and $>80 \%$ percentile; right panel shows the hygroscopic fraction $\left(F_{\text {hygro }}\right)$ and averaged $\kappa$ (on right axis) of BC-containing particles as a function of the volume fractions of the particular chemical component, the error bars indicate \pm one standard deviation.

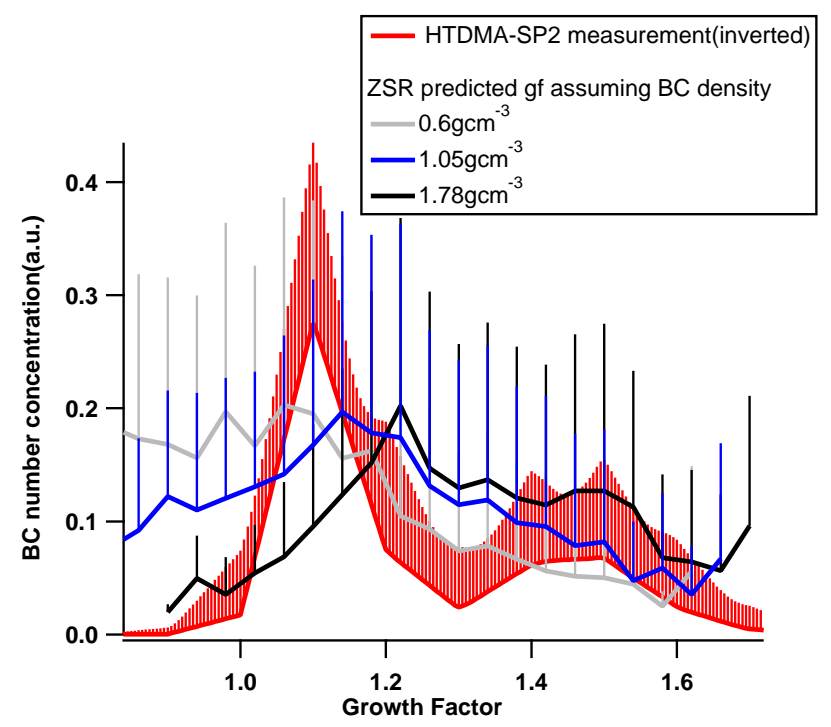

Fig. 9. A comparison between HTDMA-SP2 measured gf of BCcontaining particles and ZSR predicted gf by resolving the $\mathrm{BC}$ mixing state. The error bars show the $+\sigma$ (standard deviation) for the entire experimental period. $\kappa$ measured at sub-saturation can be used to calculate the threshold supersaturation above which a given size of particle can be CCN activated. However, the theoretical basis of the relationship restricts its application to particles solely comprising involatile compounds and water. According to Topping and McFiggans (2012), if a substantial fraction of particles contains semi-volatile organic compounds in addition to containing semi-volatile inorganic components such as ammonium nitrate, the co-condensation effect will substantially decrease the saturation ratio of water vapour required for droplet activation. Given the BC-containing particles in this study are significantly coated with semi-volatile organic and nitrate compositions, the co-condensation effect may introduce considerable uncertainties when calculating the $\mathrm{CCN}$ activities under supersaturation conditions. Therefore the $F_{\text {hygro }}$ as calculated in this study is only a first but not explicit estimation on the faction of BC-containing particles that are more likely to be $\mathrm{CCN}$-activated in the real atmosphere.

As Fig. 7 and Table 1 show, the organic component is often the largest contribution to the total non- $\mathrm{BC}$ volume of $\mathrm{BC}$ containing particles $(\varepsilon \sim 0.15-0.50)$. The organic coating can be both the primary organic matter co-emitted from combustion sources with soot particles, and secondary 
organic matter condensed onto soot particles during transport. The nitrate or sulphate will be almost entirely secondary in nature. The occasionally observed high nitrate or sulphate coating fraction coincided with the pollutant events containing high total loadings of nitrate or sulphate (Fig. 3). Although the nitrate/sulphate coatings provide lower volume fractions on average $(\varepsilon \sim 0.04-0.22)$, they contribute significantly to the hygroscopicity of BC-containing particles because of their highly hygroscopic properties.

As Table 1 summarizes, the fraction of $\mathrm{rBC}$ did not exhibit significant variance among different air masses $(\varepsilon \sim 0.45-$ 0.75 ), equivalent to a non-refractory volume fraction of 0.25 0.55 . Most of the $\mathrm{BC}$ particles from different air masses arriving at the site have been considerably aged and mixed since emission, showing a relatively consistent mixing state irrespective of their regional origin. The organic coating content also appears to be independent of air masses. Higher nitrate mass fractions of $\mathrm{BC}$-containing particles were observed in air masses from continental Europe and central England, which is consistent with higher mass loading of nitrate that were also observed from these regions. The BC from North Sea air mass contained a more significant fraction of sulphate coating. For the cleaner air masses from the Arctic and Atlantic, the nitrate fraction was significantly reduced and the sulphate fraction became dominant.

The gf of BC-containing particles exhibited apparent bimodality, as shown in Fig. 8 left panel. The hygroscopicity of BC-containing particles, as reflected by distribution of $\mathrm{gf}$, $\kappa$ and the $F_{\text {hygro }}$, were significantly controlled by their chemical compositions. BC particles associated with substantial amount of non-refractory materials ( $\mathrm{rBC}$ volume fraction $>0.5$; non-refractory volume fraction $>0.5$ ) have significantly increased $F_{\text {hygro }}$ from $\sim 0.23 \pm 0.16(\kappa \sim 0.07 \pm 0.05)$ up to $\sim 0.5 \pm 0.2(\kappa \sim 0.16 \pm 0.04)$. Mixing of organic material in $\mathrm{BC}$ particles did not enhance hygroscopicity greatly, as Fig. 8 panel c shows, the gf of the more hygroscopic mode of BC particles deceased from $\sim 1.45$ to $\sim 1.3$ when the organic material contributed $40 \%$ volume in particle. It was also observed that the presence of nitrate or sulphate significantly increased the hygroscopicity of BC particles, i.e. a nitrate coating ( $\varepsilon$ from $\sim 3 \%$ to $\sim 24 \%$ ) increased $F_{\text {hygro }}$ from $\sim 0.23 \pm 0.16(\kappa \sim 0.07 \pm 0.05)$ to $\sim 0.58 \pm 0.11(\kappa \sim 0.15 \pm$ 0.05 ); a sulphate coating ( $\varepsilon$ from $\sim 2 \%$ to $\sim 20 \%$ ) increased $F_{\text {hygro }}$ from $\sim 0.22 \pm 0.17(\kappa \sim 0.06 \pm 0.05)$ to $\sim 0.49 \pm 0.15$ $(\kappa \sim 0.13 \pm 0.06)$; and a positive correlation between the nitrate/sulphate fraction and $\mathrm{BC}$ particle hygroscopicity was clearly observed.

These results address the importance of components mixed with the $\mathrm{BC}$ on influencing the hygroscopicity of $\mathrm{BC}$ particles. The addition of secondary inorganic material to $\mathrm{BC}$ particles drives the conversion of hydrophobic $\mathrm{BC}$ to hydrophilic BC. This means in the polluted continental European outflow that contains considerable nitrate fraction (Morgan et al., 2009), the BC particles will be mixed with substan- tial amounts of nitrate and the resulting increased hygroscopicity of $\mathrm{BC}$ will reduce its atmospheric lifetime.

\subsection{Growth factor modelling}

The purpose of this modelling exercise is to determine whether the phenomena being observed here can be quantitatively predicted based on the measured compositions of the particulates (within instrumental capability) and knowledge of how hygroscopicity responds to composition. If a conventional core-shell model for a $\mathrm{BC}$-containing particle is assumed, the relative coating thickness $\left(\mathrm{CT}_{\text {rela }}\right)$ of $\mathrm{BC}$ containing particles is defined as the HTDMA selected mobility diameter $\left(D_{\mathrm{mob}}\right)$, which is $163 \mathrm{~nm}$ in this study, divided by a volume equivalent diameter of $\mathrm{rBC}$ inclusion. The volume equivalent diameter $\left(D_{\mathrm{ve}}\right)$ is given by $\sqrt[3]{\frac{6 M_{\mathrm{BCC}}}{\pi \rho_{\mathrm{BC}}}}$, where the $M_{\mathrm{rBC}}$ is the $\mathrm{rBC}$ mass directly measured by the SP2. The volume fraction of the $\mathrm{rBC}$ inclusion $\left(\varepsilon_{\mathrm{rBC}}\right)$ is then derived from the $\mathrm{CT}_{\text {rela }}$.

$$
\begin{gathered}
\mathrm{CT}_{\text {rela }}=\frac{D_{\mathrm{mob}}}{\sqrt[3]{\frac{6 M_{\mathrm{rBC}}}{\pi \rho_{\mathrm{BC}}}}} \\
\varepsilon_{\mathrm{rBC}}=\left(\frac{1}{\mathrm{CT}_{\text {rela }}}\right)^{3}
\end{gathered}
$$

The effective density of $\mathrm{rBC}, \rho_{\mathrm{BC}}$, which is used to convert the $\mathrm{rBC}$ inclusion from mass to volume, is largely influenced by the particle morphology. As previously discussed (Sect. 2.1), $\rho_{\mathrm{BC}}$ will tend to be larger when the $\mathrm{BC}$ core is coated and the particle shape is more compact. There are many factors that can modify the soot morphology in the real atmosphere, such as the amount of associated coatings, the surrounding relative humidity conditions and soot type. The $\rho_{\mathrm{BC}}$ can be further complicated by the microphysical structure of soot particles, i.e. how the coating materials will fill in the cavities of soot particle. Due to the limitation of instrumentation, the complex morphology or $\rho_{\mathrm{BC}}$ of BCcontaining particles cannot be explicitly determined in this study but will be only constrained by the upper and lower extreme estimates.

$\mathrm{A} \rho \mathrm{BC}_{\max }$ of $1.78 \mathrm{~g} \mathrm{~cm}^{-3}$ is an upper estimate obtained by assuming the $\mathrm{BC}$ is a void-free sphere (Bond and Bergström, 2006). The lower estimate of $\rho_{\mathrm{BC}}$ during this experiment obtained by assuming the $\mathrm{BC}$ associated with measured $\mathrm{gf} \sim 1$ is not coated $\left(\mathrm{CT}_{\text {rela }}=1\right)$, and the entire particle is composed of black carbon. Given the particles all have a $D_{\mathrm{mob}}=163 \mathrm{~nm}$ and $M_{\mathrm{rBC}}$ is measured, $\rho_{\mathrm{BC}}$ is about $0.6 \mathrm{~g} \mathrm{~cm}^{-3}$ from Eq. (3).

$\rho_{\mathrm{BC}_{\min }}=\frac{6 M_{\mathrm{rBC}(\mathrm{gf} \sim 1)}}{\pi D_{\mathrm{mob}^{3}}}$

Given pure externally-mixed BC particles containing no other components are likely not found in the ambient environment, and even coated BC particles are sometimes not 
able to exhibit measurable gf, Eq. (3) will give a lower estimate of $\rho_{\mathrm{BC}}$. Park et al. (2003) found a $\rho_{\mathrm{BC}} \sim 0.10$ $0.70 \mathrm{~g} \mathrm{~cm}^{-3}$ for fresh diesel soot particles at diameters 200 $300 \mathrm{~nm}$. The $\rho \mathrm{BC}_{\min }$ obtained in this study is towards the higher end of this range for fresh diesel soot, because even the fresher $\mathrm{BC}$ particles observed at this rural site have been considerably processed and mixed. By varying the $\rho_{\mathrm{BC}}$ within the range ( $\left.\rho_{\mathrm{BC} \text { min }}, \rho_{\mathrm{BC} \text { max }}\right)$, the range of $\mathrm{rBC}$ volume fraction $\left(\varepsilon_{\mathrm{rBC}}\right)$ can be estimated.

The volume fractions of non-rBC coating components in BC-containing particles are estimated from the SP-AMS measurements. The advantage of this technique over the traditional AMS is that it exclusively vaporises BC-containing particles, so gives a more realistic estimation of non-BC coating compositions. The molar number of ions for inorganic salt solution coatings is calculated by a simplified ion pairing scheme by assuming the $\mathrm{NO}_{3}^{-}$and $\mathrm{SO}_{4}^{2-}$ are fully neutralized by $\mathrm{NH}_{4}^{+}$, thus in this scenario the non- $\mathrm{BC}$ compositions are simplified as $\mathrm{NH}_{4} \mathrm{NO}_{3},\left(\mathrm{NH}_{4}\right)_{2} \mathrm{SO}_{4}$ and organic matter. The chemical reaction of sulphate has not been included in this calculation. It is assumed that the $\mathrm{BC}$-containing particles observed do not contain sodium chloride. As sea salt and $\mathrm{BC}$ are both primary aerosols, it is not possible for them to become internally mixed through secondary aerosol formation, although it may be possible for them to mix through coagulation. However, the lack of a high growth factor mode in the HTDMA-CPC (e.g. Allan et al., 2009) would suggest that sea salt is not an important contributor to the number concentrations at the dry sizes under investigation here. As the AMS does not measure sea salt, it is difficult to critically assess whether including this improves closure.

The mass of each coating component is denoted as $M_{i}$ in Eq. (4), and the dry density of $\mathrm{NH}_{4} \mathrm{NO}_{3},\left(\mathrm{NH}_{4}\right)_{2} \mathrm{SO}_{4}$ and organic matter is chosen to be $1.72 \mathrm{~g} \mathrm{~cm}^{-3}, 1.77 \mathrm{~g} \mathrm{~cm}^{-3}$ and $1.40 \mathrm{~g} \mathrm{~cm}^{-3}$ respectively (Topping et al., 2005; Gysel et al., 2007). The volume fraction of each coating component $\left(M_{i}\right)$ is calculated from the mass of each coating component divided by the respective dry density. One of the uncertainties of this calculation is the SP-AMS data has not been sizeresolved due to signal to noise limitations, thus this scheme assumes the different coating components are equally distributed across different sizes of BC-containing particles.

$V_{\text {coating }}=\sum_{i} \frac{M_{i}}{\rho_{i}}$

( $M_{i}$ and $\rho_{i}$ are the mass and density of $i$-th coating components in BC-containing particles)

$\varepsilon_{i}=\left[1-\left(\frac{1}{\mathrm{CT}_{\text {rela }}}\right)^{3}\right] \times \frac{M_{i}}{\rho_{i} V_{\text {coating }}}$

The growth factor $\left(\mathrm{gf}_{\mathrm{ZSR}}\right)$ of $\mathrm{BC}$-containing particles is predicted following the Zdanovskii-Stokes-Robinson (ZSR) mixing rule (Stokes and Robinson, 1966). The ZSR assumes that at a specific relative humidity $(\mathrm{RH})$, which is $90 \%$ in this study, the total water uptake on a dry particle with mixed components is equal to the sum of the water uptake associated with each of the individual components in the form of a pure substance in the dry particle based on their volumeequivalent abundance, expressed in Eq. (6):

$\mathrm{gf}_{\mathrm{ZSR}}\left(\mathrm{RH}, D_{\mathrm{P}}\right)=\left(\sum_{i} \mathrm{gf}_{i}\left(\mathrm{RH}, D_{\mathrm{P}}\right)^{3} \varepsilon_{i}\right)^{1 / 3}$

The $\varepsilon_{i}$ is the volume fractions of $\mathrm{rBC}$, nitrate coating, sulphate coating and organic coating in $\mathrm{BC}$-containing particle, as calculated by Eqs. (1) to (5). The $\mathrm{gf}_{i}$ of the pure substance, where $\mathrm{i}$ is $\mathrm{BC}, \mathrm{NH}_{4} \mathrm{NO}_{3},\left(\mathrm{NH}_{4}\right)_{2} \mathrm{SO}_{4}$ or organic matter, are calculated using the ADDEM model (Topping et al., 2005) to be $1.0,1.81,1.71$ and 1.18 respectively at RH $90 \%$ for a dry size of $163 \mathrm{~nm}$. In a previous study, reasonable closure has been reached between the measured and ZSR predicted gf at the same site for the entire ensemble of aerosol particles using ADDEM inputs (Gysel et al., 2007); here we specifically focus on the of of $\mathrm{BC}$-containing particles.

The growth factor distributions of $\mathrm{BC}$-containing particles as measured by HTDMA-SP2 ( $\mathrm{gf}_{\mathrm{HTDMA}} \mathrm{SP} 2$ ) and predicted by ZSR model ( $\mathrm{gf}_{\mathrm{ZSR}}$ ) are shown in Fig. 9. The $\mathrm{gf}_{\mathrm{ZSR}}$ of BC-containing particles at $D_{\mathrm{mob}}=163 \mathrm{~nm}$ is calculated and averaged for each HTDMA gf scan. Due to the uncertain morphology of $\mathrm{rBC}$, the effective density of $\mathrm{rBC} \rho_{\mathrm{eff}}$ which is used for mass-to-volume conversion, is only constrained by the upper and lower extreme estimates (Sect. 2.3). The $\rho_{\text {eff }} \sim 1.05 \mathrm{~g} \mathrm{~cm}^{-3}$ is obtained when the overall modelled bias ( $\left.\mathrm{gf}_{\mathrm{ZSR}}-\mathrm{g} \mathrm{f}_{\mathrm{HTDMA}} \mathrm{SP} 2\right) / \mathrm{gf} \mathrm{HTDMA}_{\mathrm{H}} \mathrm{SP}$ is minimized. The modelled gf ZSR as shown in Fig. 9, covers a similar range compared to the $\mathrm{gf}_{\mathrm{HTDMA}-\mathrm{SP} 2}$, consistently indicating a dominant less hygroscopic mode and an extended fraction of more hygroscopic mode. The $\mathrm{gf}_{\mathrm{HTDMA}} \mathrm{SP2}$ clearly shows a bimodal distribution however the $\mathrm{gf}_{\mathrm{ZSR}}$ has not captured the bimodality but is more broadly distributed. This is almost certainly because this model treatment assumes that the non-refractory material is uniformly mixed at a given point in time, however this is very unlikely to be realistic, as the less hygroscopic mode is likely to be mixed exclusively with primary organic material, whereas the more hygroscopic BCcontaining particles may have been mainly mixed with secondary nitrate or sulphate materials. There are some other possibilities, i.e. the $\mathrm{BC}$ particles may need some organic materials to add some water in order for inorganic to condense. The SP-AMS is unable to resolve this mixing state, so this may be considered a limitation of the instrumentation. The uncertainty of assumed $\mathrm{rBC} \rho_{\text {eff }}$ results in a major variability of ZSR prediction. The $\rho_{\text {eff }}$ is highly dependent on the soot morphology (Sect. 2.1), i.e. at the higher end of gf, the BC-containing particle is mostly more coated and compact, thus the $\rho_{\text {eff }}$ will tend to be larger, conversely, at lower gf, the more fractal soot will have smaller $\rho_{\text {eff }}$. This study 


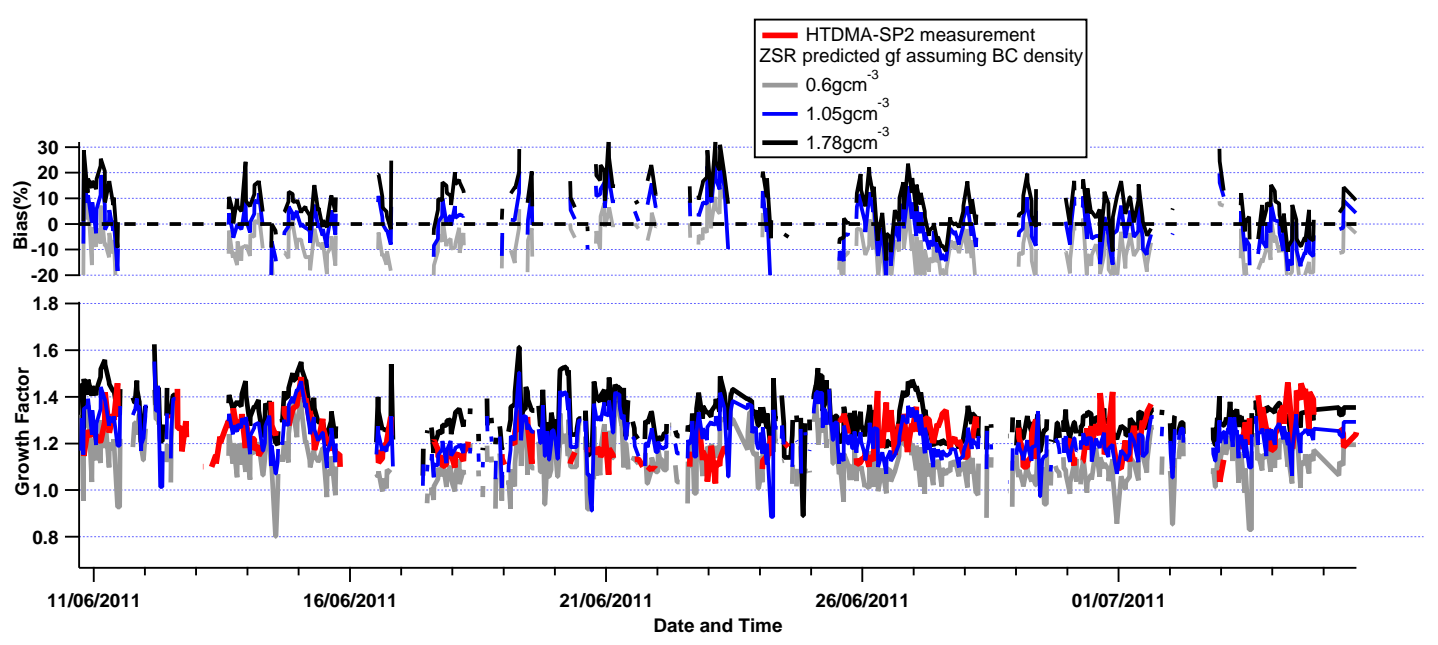

Fig. 10. Time series of the averaged gf for each complete HTDMA scan: HTDMA-SP2 measured gf, ZSR predicted gf by assuming different $\mathrm{rBC} \rho_{\text {eff }}$. The top panel shows the biases, given as $\left(\mathrm{gf}_{\mathrm{ZSR}}-\mathrm{gf}_{\mathrm{HTDMA}} \mathrm{SP} 2\right) / \mathrm{gf}_{\mathrm{HTDMA}} \mathrm{SP} 2 \times 100 \%$ for each assumed $\mathrm{rBC} \rho_{\mathrm{eff}}$.

is unable to determine the $\rho_{\text {eff }}$ for $\mathrm{BC}$ particles with different morphology, but only assumes a constant $\rho_{\text {eff }}$ throughout the experiment. The ZSR modelling on BC particle could be improved by explicit knowledge of particle morphology and mixing state of coating materials.

The bias between $\mathrm{gf}_{\mathrm{ZSR}}$ and $\mathrm{gf}_{\mathrm{HTDMA}-\mathrm{SP} 2}$ at different assumed $\rho_{\text {eff }}$ is within $\pm 30 \%$ (Fig. 10). The $\rho_{\text {eff }} \sim 1.05 \mathrm{~g} \mathrm{~cm}^{-3}$ is obtained when the overall bias for the entire experiment is minimized. However, the assumed $\rho_{\text {eff }}$, at which the optimized closure between $\mathrm{gf}_{\mathrm{ZSR}}$ and $\mathrm{gf}_{\mathrm{HTDMA}-\mathrm{SP} 2}$ is reached, was different for different periods, for example, during 20/06-23/06, the best closure was reached by assuming the lower $\rho_{\text {eff }}=0.6 \mathrm{~g} \mathrm{~cm}^{-3}$, whereas during $04 / 07$, the upper estimate $\rho_{\text {eff }}=1.78 \mathrm{~g} \mathrm{~cm}^{-3}$ got the best closure. This could indicate that the exact $\mathrm{rBC} \rho_{\text {eff }}$ or complex soot morphology was varying throughout the experiment. In the real atmosphere, to what extent the soot particle will be reconstructed by the coating will depend on soot type, the amount of coating associated with soot particles, the viscosity of the coating components and the subsequent water adsorption, e.g. by exposing hygroscopic soot to elevated RH conditions will cause enhanced reconstruction effect (i.e. Lewis et al., 2009). The undermined shape effect on $\rho_{\text {eff }}$ leads to a challenge in explicitly explaining the hygroscopic growth of $\mathrm{BC}$ particles.

\section{Summary}

The hygroscopicity of $\mathrm{BC}$ particles experiencing regional transport has been observed and quantified in this study. The hygroscopic growth factors of $\mathrm{BC}$ particles $\left(\mathrm{gf}_{\mathrm{BC}}\right.$, $\mathrm{RH}=90 \%, D_{\mathrm{mob}}=163 \mathrm{~nm}$ ) were directly measured by the HTDMA-SP2 system, and the non-refractory components mixed with the BC particles were quantitatively determined by the SP-AMS and linked to the modification of hygro- scopicity. Besides the persistently existing less-hygroscopic mode at a $\mathrm{gf}_{\mathrm{BC}} \sim 1.05$, a more-hygroscopic mode of $\mathrm{BC}$ particles was observed throughout the experiment, extending the $\mathrm{gf}_{\mathrm{BC}}$ up to $\sim 1.4-1.6$. The $\mathrm{gf}_{\mathrm{BC}}$ was observed to be highly influenced by non-BC components: the increase of $\mathrm{gf}_{\mathrm{BC}}$ was positively associated with the elevation of secondary inorganic material, being most pronounced for ammonium nitrate; however the $\mathrm{gf}_{\mathrm{BC}}$ was suppressed by the increase of organic coating content. Modelling the BC hygroscopic properties using a simplified mixing rule approach (ZSR) goes some way to explaining of the observed $\mathrm{BC}$ hygroscopicity, showing an agreement in predicted and measured gf of $\pm 30 \%$. However, the method is reliant on knowing the particle volume and this is subject to uncertainty because of the uncertain effective density of $\mathrm{BC}$ component. The model was also limited by the lack of explicit data on the soot morphology and exact mixing state of the coating materials.

The conversion process for $\mathrm{BC}$ particles from hydrophobic to hydrophilic in the real atmosphere is still not sufficiently constrained, representing a major uncertainty in determining the atmospheric lifetime of BC particles (Koch et al., 2009; Textor et al., 2006). This study highlights the importance of $\mathrm{BC}$ mixing state (including the amount of each component in the mixed particles) on influencing the $\mathrm{BC}$ hygroscopic properties. It is especially the case when $\mathrm{BC}$ particles were mixed with nitrate, during regional transport events from the UK mainland and continental Europe when their hygroscopicity was significantly enhanced. The role of nitrate for $\mathrm{BC}$ aging has been pointed out by a number of modelling studies on the mesoscale as well as the process scale (e.g. Riemer et al., 2004; Riemer et al., 2010). Given that nitrate is more rapidly formed compared to sulphate in polluted plumes and its ubiquitous presence in many areas such as Western Europe, it will significantly enhance the hydrophobic-to-hydrophilic conversion of $\mathrm{BC}$ particles, leading to a reduced atmospheric 
lifetime of $\mathrm{BC}$ in regionally polluted air masses. This stresses the importance of including this component in $\mathrm{BC}$ ageing schemes in modelling activities.

Acknowledgements. This work was supported by the UK Natural Environment Research Council (NERC) through: the grant Multiscale Chemical Composition of Carbonaceous particles and Coatings (MC4) [Grant ref: NE/H008136/1] and a PhD studentship (Dominique Young) and the National Centre for Atmospheric Science (NCAS). We would like to thank Alistair Manning and the Met Office for expertise and use of the NAME model.

Edited by: R. Krejci

\section{References}

Allan, J. D., Coe, H., Bower, K. N., Alfarra, M. R., Delia, A. E., Jimenez, J. L., Middlebrook, A. M., Drewnick, F., Onasch, T. B., Canagaratna, M. R., Jayne, J. T., et al.: A generalised method for the extraction of chemically resolved mass spectra from Aerodyne aerosol mass spectrometer data, J. Aerosol Sci., 35, 909922, 2004

Allan, J. D., Topping, D. O., Good, N., Irwin, M., Flynn, M., Williams, P. I., Coe, H., Baker, A. R., Martino, M., Niedermeier, N., Wiedensohler, A., Lehmann, S., Müller, K., Herrmann, H., and McFiggans, G.: Composition and properties of atmospheric particles in the eastern Atlantic and impacts on gas phase uptake rates, Atmos. Chem. Phys., 9, 9299-9314, doi:10.5194/acp-9-9299-2009, 2009.

Aubin, D. G. and Abbatt, J. P. D.: Interaction of $\mathrm{NO}_{2}$ with hydrocarbon soot: Focus on HONO yield, surface modification, and mechanism, J. Phys. Chem. A, 111, 6263-6273, doi:10.1021/jp068884h, 2007.

Baumgardner, D., Kok, G., and Raga, G.: Warming of the Arctic lower stratosphere by light absorbing particles, Geophys. Res. Lett., 31, L06117, doi:10.1029/2003GL018883, 2004.

Baumgardner, D., Popovicheva, O., Allan, J., Bernardoni, V., Cao, J., Cavalli, F., Cozic, J., Diapouli, E., Eleftheriadis, K., Genberg, P. J., Gonzalez, C., Gysel, M., John, A., Kirchstetter, T. W., Kuhlbusch, T. A. J., Laborde, M., Lack, D., Müller, T., Niessner, R., Petzold, A., Piazzalunga, A., Putaud, J. P., Schwarz, J., Sheridan, P., Subramanian, R., Swietlicki, E., Valli, G., Vecchi, R., and Viana, M.: Soot Reference Materials for instrument calibration and intercomparisons: a workshop summary with recommendations, Atmos. Meas. Tech. Discuss., 5, 23152362, doi:10.5194/amtd-5-2315-2012, 2012.

Bond, T. C. and Bergstrom, R. W.: Light absorption by carbonaceous particles: An investigative review, Aerosol Sci. Technol., 40, 27-67, 2006.

Canagaratna, M. R., Jayne, J. T., Jimenez, J. L., Allan, J. D., Alfarra, M. R., Zhang, Q., Onasch, T. B., Drewnick, F., Coe, H., Middlebrook, A., Delia, A., Williams, L. R., Trimborn, A. M., Northway, M. J., DeCarlo, P. F., Kolb, C. E., Davidovits, P., and Worsnop, D. R.: Chemical and microphysical characterization of ambient aerosols with the Aerodyne aerosol mass spectrometer, Mass Spectrom. Rev., 26, 185-222, 2007.
Cubison, M. J., Coe, H., and Gysel, M.: A modified hygroscopic tandem DMA and a data retrieval method based on optimal estimation, J. Aerosol Sci., 36, 846-865, 2005.

DeCarlo, P. F., Slowik, J. G., Worsnop, D. R., Davidovits, P. and Jimenez, J. L.: Particle morphology and density characterization by combined mobility and aerodynamic diameter measurements. Part 1: theory. Aerosol Sci. Technol., 38, doi:10.1080/027868290903907, 2004.

DeCarlo, P. F., Kimmel, J. R., Trimborn, A., Northway, M. J., Jayne, J. T., Aiken, A. C., Gonin, M., Fuhrer, K., Horvath, T., Docherty, K. S., Worsnop, D. R., and Jimenez, J. L.: Field-deployable, high-resolution, time-of-flight aerosol mass spectrometer, Anal Chem., 78, 8281-8289, 2006.

Duplissy, J., Gysel, M., Sjogren, S., Meyer, N., Good, N., Kammermann, L., Michaud, V., Weigel, R., Martins dos Santos, S., Gruening, C., Villani, P., Laj, P., Sellegri, K., Metzger, A., McFiggans, G. B., Wehrle, G., Richter, R., Dommen, J., Ristovski, Z., Baltensperger, U., and Weingartner, E.: Intercomparison study of six HTDMAs: results and recommendations, Atmos. Meas. Tech., 2, 363-378, doi:10.5194/amt-2-363-2009, 2009.

Dusek, U., Reischl, G. P., and Hitzenberger, R.: CCN activation of pure and coated carbon black particles, Environ. Sci. Technol., 40, 1223-1230, 2006.

Fleming, Z. L., Monks, P. S., and Manning, A. J.: Review: Untangling the influence of air-mass history in interpreting observed atmospheric composition, Atmospheric Research, 104-105, 139, 2012

Gysel, M., Nyeki, S., Weingartner, E., Baltensperger, U., Giebl, H., Hitzenberger, R., Petzold, A., and Wilson, C. W.: Properties of jet engine combustion particles during the PartEmis experiment: Hygroscopicity at subsaturated conditions, Geophys. Res. Lett., 30, 1566, doi:10.1029/2003GL016896, 2003.

Gysel, M., Crosier, J., Topping, D. O., Whitehead, J. D., Bower, K. N., Cubison, M. J., Williams, P. I., Flynn, M. J., McFiggans, G. B., and Coe, H.: Closure study between chemical composition and hygroscopic growth of aerosol particles during TORCH2, Atmos. Chem. Phys., 7, 6131-6144, doi:10.5194/acp7-6131-2007, 2007.

Gysel, M., McFiggans, G. B., and Coe, H.: Inversion of tandem differential mobility analyser (TDMA) measurements, J. Aerosol Sci., 40, 134-151, 2009.

Gysel, M., Laborde, M., Olfert, J. S., Subramanian, R., and Gröhn, A. J.: Effective density of Aquadag and fullerene soot black carbon reference materials used for SP2 calibration, Atmos. Meas. Tech., 4, 2851-2858, doi:10.5194/amt-4-2851-2011, 2011.

Henning, S.,Wex, H.,Wennrich, C., Hennig, T., Kiselev, A., Snider, J. R., Rose, D., Dusek, U., Frank, G. P., Pöschl, U., Kristensson, A., Bilde, M., Tillmann, R., Kiendler-Scharr, A., Mentel, Th. F., Walter, S., Schneider, J., and Stratmann, F.: Soluble mass, hygroscopic growth, and droplet activation of coated soot particles during LACIS Experiment in November (LExNo), J. Geophys. Res., 115, D11206, doi:10.1029/2009JD012626, 2010.

Jacobson, M. Z.: Short-effects of controlling fossil-soot, biofuel soot and gases, and methane on climate, Arctic ice, and air pollution health, J. Geophys. Res., 115, D14209, doi:10.1029/2009JD013795, 2010.

Khalizov, A. F, Zhang, R., Zhang, D., Xue, H., Pagels, J., and McMurry, P. H.: Formation of highly hygroscopic soot aerosols 
upon internal mixing with sulfuric acid vapor, J. Geophys. Res., 114, D05208, doi:10.1029/2008JD010595, 2009.

Kiselev, A., Wennrich, C., Stratmann, F., Wex, H., Henning, S., Mentel, T. F., Kiendler-Scharr, A., Schneider, J., Walter, S., and Lieberwirth, I.: Morphological characterization of soot aerosol particles during LACIS Experiment in November (LExNo), J. Geophys. Res., 115, D11204, doi:10.1029/2009JD012635, 2010.

Koch, D., Schulz, M., Kinne, S., McNaughton, C., Spackman, J. R., Balkanski, Y., Bauer, S., Berntsen, T., Bond, T. C., Boucher, O., Chin, M., Clarke, A., De Luca, N., Dentener, F., Diehl, T., Dubovik, O., Easter, R., Fahey, D. W., Feichter, J., Fillmore, D., Freitag, S., Ghan, S., Ginoux, P., Gong, S., Horowitz, L., Iversen, T., Kirkevåg, A., Klimont, Z., Kondo, Y., Krol, M., Liu, X., Miller, R., Montanaro, V., Moteki, N., Myhre, G., Penner, J. E., Perlwitz, J., Pitari, G., Reddy, S., Sahu, L., Sakamoto, H., Schuster, G., Schwarz, J. P., Seland, Ø., Stier, P., Takegawa, N., Takemura, T., Textor, C., van Aardenne, J. A., and Zhao, Y.: Evaluation of black carbon estimations in global aerosol models, Atmos. Chem. Phys., 9, 9001-9026, doi:10.5194/acp-9-9001-2009, 2009.

Koch, D. and Del Genio, A. D.: Black carbon semi-direct effects on cloud cover: review and synthesis, Atmos. Chem. Phys., 10, 7685-7696, doi:10.5194/acp-10-7685-2010, 2010.

Koehler, K. A., DeMott, P. J., Kreidenweis, S. M., Popovicheva, O., Petters, M. D., Carrico, C. M., Kireeva, E., Khokhlova, T., and Shonija, N.: Cloud condensation nuclei and ice nucleation activity of hydrophobic and hydrophilic soot particles, Phys. Chem. Chem. Phys., 11, 7906-7920, doi:10.1039/b905334b, 2009.

Kuwata, M., Kondo, Y., Mochida, M., Takegawa, N., and Kawamura, K.: Dependence of CCN activity of less volatile particles on the amount of coating observed in Tokyo, J. Geophys. Res., 112, D11207, doi:10.1029/2006JD007758, 2007.

Laborde, M., Schnaiter, M., Linke, C., Saathoff, H., Naumann, K.H., Möhler, O., Berlenz, S., Wagner, U., Taylor, J. W., Liu, D., Flynn, M., Allan, J. D., Coe, H., Heimerl, K., Dahlkötter, F., Weinzierl, B., Wollny, A. G., Zanatta, M., Cozic, J., Laj, P., Hitzenberger, R., Schwarz, J. P., and Gysel, M.: Single Particle Soot Photometer intercomparison at the AIDA chamber, Atmos. Meas. Tech., 5, 3077-3097, doi:10.5194/amt-5-3077-2012, 2012.

Lammel, G. and Novakov, T.: Water nucleation properties of carbon-black and diesel soot particles, Atmos. Environ., 29, 813823, 1995.

Lewis, K. A., Arnott, W. P., Moosmüller, H., Chakrabarty, R. K., Carrico, C. M., Kreidenweis, S. M., Day, D. E., Malm, W. C., Laskin, A., Jimenez, J. L., Ulbrich, I. M., Huffman, J. A., Onasch, T. B., Trimborn, A., Liu, L., and Mishchenko, M. I.: Reduction in biomass burning aerosol light absorption upon humidification: roles of inorganically-induced hygroscopicity, particle collapse, and photoacoustic heat and mass transfer, Atmos. Chem. Phys., 9, 8949-8966, doi:10.5194/acp-9-8949-2009, 2009.

Liu, D., Flynn, M., Gysel M., Targino, A., Crawford, I., Bower, K., Choularton, T., Juranyi, Z., Steinbacher, M., Huglin, C., Curtius, J., Kampus, M., Petzold, A.,Weingartner, E., Baltensperger, U., and Coe, H.: Single particle characterization of black carbon aerosols at a tropospheric alpine site in Switzerland, Atmos. Chem. Phys., 10, 7389-7407, doi:10.5194/acp-10-73892010, 2010.
McFiggans, G., Artaxo, P., Baltensperger, U., Coe, H., Facchini, M. C., Feingold, G., Fuzzi, S., Gysel, M., Laaksonen, A., Lohmann, U., Mentel, T. F., Murphy, D. M., O’Dowd, C. D., Snider, J. R., and Weingartner, E.: The effect of physical and chemical aerosol properties on warm cloud droplet activation, Atmos. Chem. Phys., 6, 2593-2649, doi:10.5194/acp-6-25932006, 2006.

McMeeking, G. R., Hamburger, T., Liu, D., Flynn, M., Morgan, W. T., Northway, M., Highwood, E. J., Krejci, R., Allan, J. D., Minikin, A., and Coe, H.: Black carbon measurements in the boundary layer over western and northern Europe, Atmos. Chem. Phys., 10, 9393-9414, doi:10.5194/acp-10-9393-2010, 2010.

McMeeking, G. R., Good, N., Petters, M. D., McFiggans, G., and Coe, H.: Influences on the fraction of hydrophobic and hydrophilic black carbon in the atmosphere, Atmos. Chem. Phys., 11, 5099-5112, doi:10.5194/acp-11-5099-2011, 2011.

Morgan, W. T., Allan, J. D., Bower, K. N., Capes, G., Crosier, J., Williams, P. I., and Coe, H.: Vertical distribution of sub-micron aerosol chemical composition from North-Western Europe and the North-East Atlantic, Atmos. Chem. Phys., 9, 5389-5401, doi:10.5194/acp-9-5389-2009, 2009.

Onasch, T. B., Trimborn, A., Fortner, E. C., Jayne, J. T., Kok, G. L., Williams, L. R., Davidovits, P. and Worsnop, D. R.: Soot Particle Aerosol Mass Spectrometer: Development, Validation, and Initial Application, Aerosol Sci. Tech., 46, 804-817, doi:10.1080/02786826.2012.663948, 2012.

Pagels, J., Khalizov, A. F., McMurry, P. H., and Zhang, R. Y.: Processing of soot by controlled sulphuric acid and water condensation-Mass and mobility relationships, Aerosol Sci. Technol., 43, 629-640, 2009.

Park, K., Cao, F., Kittelson, D. B., and McMurry, P. H.: Relationship between particle mass and mobility for diesel exhaust particles, Environ. Sci. Technol., 37, 577-83, 2003.

Penkett, S. A., Burgess, R. A., Coe, H., Coll, I., Hov, O., Lindskog, A., Schmidbauer, N., Solberg, S., Roemer, M., Thijsse, T., Beck, J., Reeves, C. E.: Evidence for large average concentrations of the nitrate radical (NO3) in Western Europe from the HANSA hydrocarbon database, Atmos. Environ., 41, 3465-3478, 2007.

Petters, M. D. and Kreidenweis, S. M.: A single parameter representation of hygroscopic growth and cloud condensation nucleus activity, Atmos. Chem. Phys., 7, 1961-1971, doi:10.5194/acp-71961-2007, 2007.

Petzold, A., Gysel, M., Vancassel, X., Hitzenberger, R., Puxbaum, H., Vrochticky, S., Weingartner, E., Baltensperger, U., and Mirabel, P.: On the effects of organic matter and sulphurcontaining compounds on the $\mathrm{CCN}$ activation of combustion particles, Atmos. Chem. Phys., 5, 3187-3203, doi:10.5194/acp5-3187-2005, 2005.

Ramanathan, V. and Carmichael, G.: Global and regional climate changes due to black carbon, Nat. Geosci., 1, 221-227, 2008.

Riemer, N., Vogel, H., and Vogel, B.: Soot aging time scales in polluted regions during day and night, Atmos. Chem. Phys., 4, 1885-1893, doi:10.5194/acp-4-1885-2004, 2004.

Riemer, N., West,M., Zaveri, R., and Easter, R.: Estimating black carbon aging time-scales with a particle resolved aerosol model, J. Aerosol Sci., 143-158, 2010.

Rose, D., Gunthe, S. S., Su, H., Garland, R. M., Yang, H., Berghof, M., Cheng, Y. F., Wehner, B., Achtert, P., Nowak, A., Wiedensohler, A., Takegawa, N., Kondo, Y., Hu, M., Zhang, Y., 
Andreae, M. O., and Pöschl, U.: Cloud condensation nuclei in polluted air and biomass burning smoke near the megacity Guangzhou, China - Part 2: Size-resolved aerosol chemical composition, diurnal cycles, and externally mixed weakly CCN-active soot particles, Atmos. Chem. Phys., 11, 2817-2836, doi:10.5194/acp-11-2817-2011, 2011.

Schwarz, J. P., Gao, R. S., Fahey, D. W., Thomson, D. S., Watts, L. A., Wilson, J. C., Reeves, J. M., Darbeheshti, M., Baumgardner, D. G., Kok, G. L., Chung, S. H., Schulz, M., Hendricks, J., Lauer, A., Karcher, B., Slowik, J. G., Rosenlof, K. H., Thompson, T. L., Langford, A. O., Loewenstein, M., and Aikin, K. C.: Single-particle measurements of midlatitude black carbon and light-scattering aerosols from the boundary layer to the lower stratosphere, J. Geophys. Res., 111, D16207, doi:10.1029/2006JD007076, 2006.

Schwarz, J. P., Gao, R. S., Spackman, J. R., Watts, L. A., Thomson, D. S., Fahey, D. W., Ryerson, T. B., Peischl, J., Holloway, J. S., Trainer, M., Frost, G. J., Baynard, T., Lack, D. A., de Gouw, J. A., Warneke, C., and Del Negro, L. A.: Measurement of the mixing state, mass, and optical size of individual black carbon particles in urban and biomass burning emissions, Geophys. Res. Lett., 35, L13810, doi:10.1029/2008GL033968, 2008.

Snider, J. R., Wex, H., Rose, D., Kristensson, A., Stratmann, F., Hennig, T., Henning, S., Kiselev, A., Bilde, M., Burkhart, M., Dusek, U., Frank, G. P., Kiendler-Scharr, A., Mentel, T. F., Petters, M. D., and Pöschl, U.: Intercomparison of cloud condensation nuclei and hygroscopic fraction measurements: Coated soot particles investigated during the LACIS Experiment in November (LExNo), J. Geophys. Res., 115, D11205, doi:10.1029/2009JD012618, 2010.

Stokes, R. H. and Robinson, R. A.: Interactions in aqueous nonelectrolyte solutions. I. Solute-solvent equilibria, J. Phys. Chem., 70, 2126-2130, 1966.

Textor, C., Schulz, M., Guibert, S., Kinne, S., Balkanski, Y., Bauer, S., Berntsen, T., Berglen, T., Boucher, O., Chin, M., Dentener, F., Diehl, T., Easter, R., Feichter, H., Fillmore, D., Ghan, S., Ginoux, P., Gong, S., Grini, A., Hendricks, J., Horowitz, L., Huang, P., Isaksen, I., Iversen, I., Kloster, S.,Koch, D., Kirkevåg, A., Kristjansson, J. E., Krol, M., Lauer, A., Lamarque, J. F., Liu, X., Montanaro, V., Myhre, G., Penner, J., Pitari, G., Reddy, S., Seland, Ø., Stier, P., Takemura, T., and Tie, X.: Analysis and quantification of the diversities of aerosol life cycles within AeroCom, Atmos. Chem. Phys., 6, 1777-1813, doi:10.5194/acp-6-1777-2006, 2006.
Topping, D. O. and McFiggans, G.: Tight coupling of particle size, number and composition in atmospheric cloud droplet activation, Atmos. Chem. Phys., 12, 3253-3260, doi:10.5194/acp-12-32532012, 2012.

Topping, D. O., McFiggans, G. B., and Coe, H.: A curved multicomponent aerosol hygroscopicity model framework: Part 1 - Inorganic compounds, Atmos. Chem. Phys., 5, 1205-1222, doi:10.5194/acp-5-1205-2005, 2005.

Tritscher, T., Jurányi, Z., Martin, M., Roberto Chirico, Gysel, M., Heringa, M. F., DeCarlo, P., Sierau, B., Prévôt, A., Weingartner, E., and Baltensperger, U.: Changes of hygroscopicity and morphology during ageing of diesel soot, Environ. Res. Lett., 6, 034026, doi:10.1088/1748-9326/6/3/034026, 2011.

Wang, J., Cubison, M. J., Aiken, A. C., Jimenez, J. L., and Collins, D. R.: The importance of aerosol mixing state and sizeresolved composition on $\mathrm{CCN}$ concentration and the variation of the importance with atmospheric aging of aerosols, Atmos. Chem. Phys., 10, 7267-7283, doi:10.5194/acp-10-7267-2010, 2010.

Weingartner, E., Burtscher, H., and Baltensperger, U.: Hygroscopic properties of carbon and diesel soot particles, Atmos. Environ., 31, 2311-2327, 1997.

Young, D., Allan, J., Flynn, M., Liu, D., Whitehead, J., Fleming, Z., Bandy B., and Coe, H.: Characterisation of regional background aerosol of the UK from a rural site, in preparation, 2013.

Zhang, D. and Zhang, R.: Laboratory investigation of heterogeneous interaction of sulfuric acid with soot, Environ. Sci. Technol., 39, 5722-5728, doi:10.1021/es050372d, 2005.

Zhang, R. Y., Khalizov, A. F., Pagels, J., Zhang, D., Xue, H., and McMurry, P. H.: Variability in morphology, hygroscopicity, and optical properties of soot aerosols during atmospheric processing, P. Natl. Acad. Sci. USA, 105, 10291-10296, doi:10.1073/pnas.0804860105, 2008.

Zuberi, B., Johnson, K. S., Aleks, G. K., Molina, L. T., Molina, M. J., and Laskin, A.: Hydrophilic properties of aged soot, Geophys. Res. Lett., 32, L01807, doi:10.1029/2004GL021496, 2005. 